\title{
THE COMPOSITION AND MODE OF FORMATION OF THE PECHENGA NICKEL DEPOSITS, KOLA PENINSULA, NORTHWESTERN RUSSIA
}

\author{
SARAH-JANE BARNES $\$$ \\ Sciences de la Terre, Université du Québec, Chicoutimi, Québec G7H 2B1, Canada \\ VICTOR A. MELEZHIK \\ Geological Survey of Norway, N-7491 Trondheim, Norway \\ STANISLAV V. SOKOLOV \\ Pechenga Nickel Kombinate, 184414 Zapolyarny, Murmansk Region, Russia
}

\begin{abstract}
The Pechenga Ni-sulfide deposits, in the Kola Peninsula of Russia, are associated with ferropicrite flows and intrusions. The sulfides are divided into five types: 1) disseminated sulfides within the olivine cumulate portions of the ferropicrites, 2) massive sulfides, which occur at the contact between the ferropicrites and the country-rock black schists, 3) breccia-matrix sulfides, which occur at the contact between the ferropicrites and the schists, and in some cases continue for hundreds of meters subparallel to the contact but within the footwall, 4) chalcopyrite vein or stringer sulfides, which occur in the footwall, and 5) pyrite-rich layers, concretions and lenses in the sedimentary rocks. The disseminated sulfides have similarly shaped mantle-normalized patterns of chalcophile metal abundances to those of the ferropicrites, and could have formed in equilibrium with the ferropicritic magma at moderate $R$ factors (250). The rocks are depleted in platinum-group elements (PGE), suggesting that the magma reached sulfide saturation prior to the formation of the ores. Sulfur isotope data indicate that the $S$ was derived from the sediments onto and into which the ferropicrites were emplaced. The high As and $\mathrm{Sb}$ concentrations in the sulfides may have been derived from the sediments. The massive sulfides show a wider variety of composition than the disseminated sulfides; some sulfides are enriched in $\mathrm{Os}, \mathrm{Ir}, \mathrm{Ru}, \mathrm{Rh}$ and depleted $\mathrm{Pt}, \mathrm{Pd}, \mathrm{Ag}, \mathrm{Au}, \mathrm{Cu}, \mathrm{Sb}, \mathrm{As}$, Se. This pattern is attributed to the accumulation of monosulfide solidsolution during crystallization of a sulfide liquid. The sedimentary sulfides are richer in As and Sb than the disseminated and massive sulfides, but poorer in all the other chalcophile elements. The breccia-matrix sulfides consist of sedimentary and ultramafic fragments in a sulfide matrix. Compared with vein sulfides from other deposits, those from Pechenga have a very unusual composition. They are not only rich in $\mathrm{Cu}$ and $\mathrm{Ag}$, but also in $\mathrm{Os}$, $\mathrm{Ir}, \mathrm{Ru}$ and $\mathrm{Rh}$, and they are depleted in $\mathrm{Pt}, \mathrm{Pd}, \mathrm{Au}, \mathrm{As}$, $\mathrm{Sb}$ and $\mathrm{Se}$.
\end{abstract}

Keywords: nickel sulfide deposits, platinum-group elements, arsenic, antimony, gold, selenium, silver, rare-earth elements, ferropicrites, sulfur isotopes, Pechenga, Russia.

\section{SOMMAIRE}

Les gisements de nickel de Pechenga, dans la péninsule de Kola, en Russie, sont associés à des coulées et des massifs intrusifs de ferropicrite. Les sulfures de nickel se présentent en cinq associations: 1) sulfures disséminés dans les parties cumulatives des ferropicrites, 2) sulfures massifs au contact entre les ferropicrites et les schistes noirs encaissants, 3) sulfures formant la matrice de brèches de ferropicrite et de schiste, dans certains cas se prolongeant des centaines de mètres le long du contact mais invariablement situés au dessus de la paroi inférieure, 4) veines de chalcopyrite ou sulfures en veinules, dans la paroi inférieure, et 5) accumulations de pyrite formant concrétions et lentilles dans l'encaissant sédimentaire. Les sulfures disséminés possèdent des tracés de concentrations en métaux chalcophiles normalisées par rapport au manteau semblables à ceux des ferropicrites, et pourraient s'être formés en équilibre avec le magma ferropicritique à un facteur $R$ moyen (250). Les roches sont appauvries en éléments du groupe du platine, ce qui indiquerait une saturation du magma en sulfures avant la formation du minerai. Les données isotopiques indiquent que le soufre a été dérivé à partir des sédiments sur et dans lesquels le magma ferropicritique s'est épanché. Les concentrations élevées d'arsenic et d'antimoine pourraient avoir une origine dans les sédiments. Les sulfures massifs montrent un intervalle de composition plus étendu que les sulfures disséminés. Dans certains cas, les sulfures montrent une enrichissement

§ E-mail address: sjbarnes@uqac.uquebec.ca 
en $\mathrm{Os}, \mathrm{Ir}, \mathrm{Ru}$ et $\mathrm{Rh}$, et un appauvrissement en $\mathrm{Pt}, \mathrm{Pd}, \mathrm{Ag}, \mathrm{Au}, \mathrm{Cu}, \mathrm{Sb}, \mathrm{As}$ et $\mathrm{Se}$. Ces caractéristiques seraient attribuables à une accumulation de solution solide monosulfurée au cours de la cristallisation du liquide sulfuré. Les sulfures d'origine sédimentaire sont plus riches en arsenic et antimoine que les sulfures disséminés et massifs, mais les autres éléments chalcophiles y sont appauvris. Les sulfures formant la matrice des brèches renferment des fragments sédimentaires et ultramafiques. En comparaison des sulfures en veines d'autres gisements, ceux de Pechenga ont une composition très inhabituelle. Ils sont enrichis non seulement en $\mathrm{Cu}$ et $\mathrm{Ag}$, mais aussi en Os, Ir, Ru et Rh, et appauvris en Pt, Pd, Au, As, Sb et $\mathrm{Se}$.

(Traduit par la Rédaction)

Mots-clés: gisements de sulfures de nickel, éléments du groupe du platine, arsenic, antimoine, or, sélénium, argent, terres rares, ferropicrite, isotopes de soufre, Pechenga, Russie.

\section{INTRODUCTION}

The nickel deposits of the Pechenga Greenstone Belt are located in the Kola Peninsula of northwestern Russia (Fig. 1). The overall size and grade of the deposits have been estimated to be $150 \mathrm{Mt}$ at approximately $1 \%$ $\mathrm{Ni}$ (Chadwick 1992), making them an ore field of intermediate size on the world scale. Nickel is found in sulfides associated with ultramafic to mafic bodies that are enclosed in pyrite-rich graphitic sedimentary units. The sulfides have been divided into four types (Gorbunov $e t$ al. 1985): 1) disseminated sulfides (both interstitial and globular), which occur toward the base of, but within, the ultramafic to mafic bodies (Fig. 2a), 2) massive sulfides (Fig. 2b), which occur at the lower contact between the ultramafic to mafic bodies and the sedimentary rocks, 3) breccia-matrix sulfides, which occur at the lower contact and for up to a kilometer along strike into the sediments, consisting of a matrix of sulfides showing tectonic flow fabric, and which contain fragments of ultramafic and sedimentary rocks (Fig. 2c), and 4) vein or stringer sulfides (Fig. 2d), which are chalcopyrite-rich veins in the country rocks. The graphitic pyrite-rich sedimentary rocks, collectively known as "black schists", which host the ore-bearing flows, contain sedimentary sulfides that make up a fifth type of sulfide ore (Fig. 2e).

In this investigation, we report analytical results for major oxides, rare-earth elements $(R E E)$, lithophile trace elements, $P G E$ (platinum-group elements), $\mathrm{Au}, \mathrm{Ni}, \mathrm{Cu}$, $\mathrm{As}, \mathrm{Sb}, \mathrm{Se}, \mathrm{S}$ and $\mathrm{S}$ isotopes for 65 samples and 24 sulfide separates collected from all of the various deposits (Fig. 3, Tables 1, 2 and 3). The aims of the work are: a) to establish the composition of the different types of sulfides, $b$ ) to determine whether there is any difference in composition between the deposits in the western and eastern ends of the belt, and c) to model the composition of each ore type.

\section{Geological Setting}

The Pechenga Greenstone Belt is a part of the larger, discontinuously developed Paleoproterozoic North Transfennoscandian Greenstone Belt, which stretches over a distance of $1000 \mathrm{~km}$ (Fig. 1a). The Pechenga Belt is composed of two groups, namely the older North Pechenga Group, which contains the Ni deposits, and the younger South Pechenga Group (Fig. 1b). The lower limit of the North Pechenga Group is defined by the emplacement age of the Mt. General'skaya intrusion ( $2505 \pm 1.6 \mathrm{Ma}$ U-Pb on baddeleyite: Amelin et al. 1995). The upper age limit is defined by ultramafic flows and intrusions of Pilgujärvi Formation (1977 \pm 52 Ma, Sm$\mathrm{Nd}$ and $\mathrm{Pb} / \mathrm{Pb}$ on mineral separates: Hanski 1992).

The North Pechenga Group consists of four sedimentary-volcanic cycles. Each cycle begins with a thin pile of sedimentary rocks and ends with a thick pile of mainly basaltic volcanic rocks (Melezhik \& Sturt 1994). The first cycle consists of locally derived conglomerates (Neverskrukk Formation) and is overlain by continental rift volcanic rocks (Ahmalakhti Formation). The Neverskrukk conglomerates lie discordantly with a firstorder unconformity and well-developed regolith on Archean basement. The next sedimentary-volcanic cycle (Kuetsjarvi Formation) begins with shallow-water sediments (quartzites, dolomites) and ends with alkali basalt. The third sedimentary-volcanic cycle (Kolasjoki Formation) begins with red sandstone and ends with tholeiitic basalt. The fourth cycle, the Pilgujärvi Formation, contains the Ni ore deposits. The sedimentary rocks consist of greywackes and shales, which contain abundant pyrite and graphite and are collectively referred to as black schists. The overlying Pilgujärvi volcanic rocks are predominately pillow basalts, interpreted to represent mid-ocean-ridge basalts (MORB). The ore deposits are associated with picrites emplaced onto and into the black schists. Each cycle of the North Pechenga Group is separated by a non-depositional unconformity generally marked by paleoweathering. The maximum cumulative stratigraphic thickness of the sedimentary and volcanic formations of the North Pechenga Group are 1,600 m and $12,000 \mathrm{~m}$, respectively. The rocks have undergone metamorphism from prehnite-pumpellyite to greenschist facies in the central part of the Pechenga Belt, and to the amphibolite facies toward its peripheral zones (Belyaev et al. 1977).

The 600- to 1000-m-thick Pilgujärvi Sedimentary Formation (also referred to as the Productive Formation) hosts all of the ultramafic bodies that contain $\mathrm{Ni}$ 


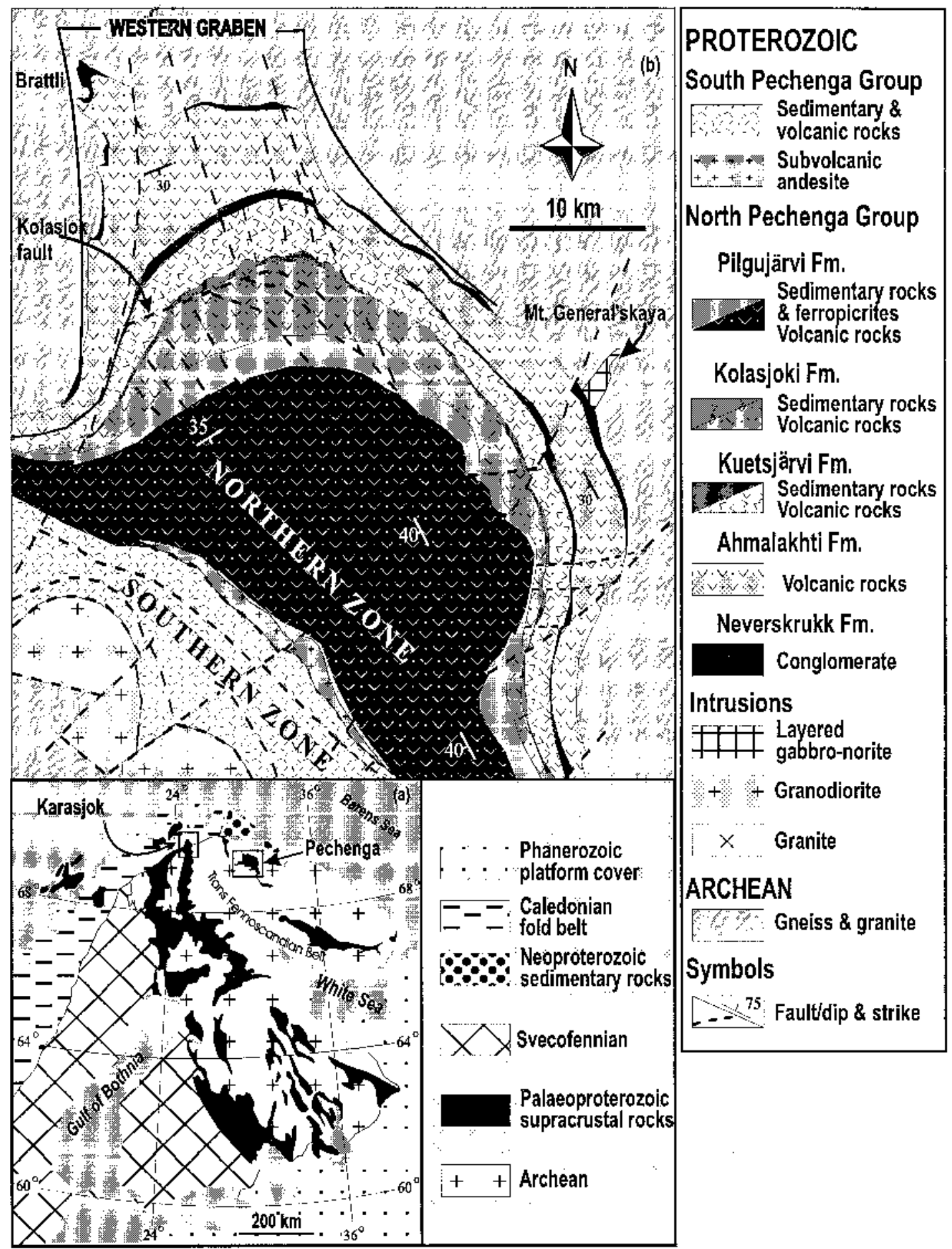

FIG. 1. The geology of the Fennoscandian Shield showing the location of the Pechenga and other Paleoproterozoic volcanosedimentary belts. 
$\mathbf{a}$
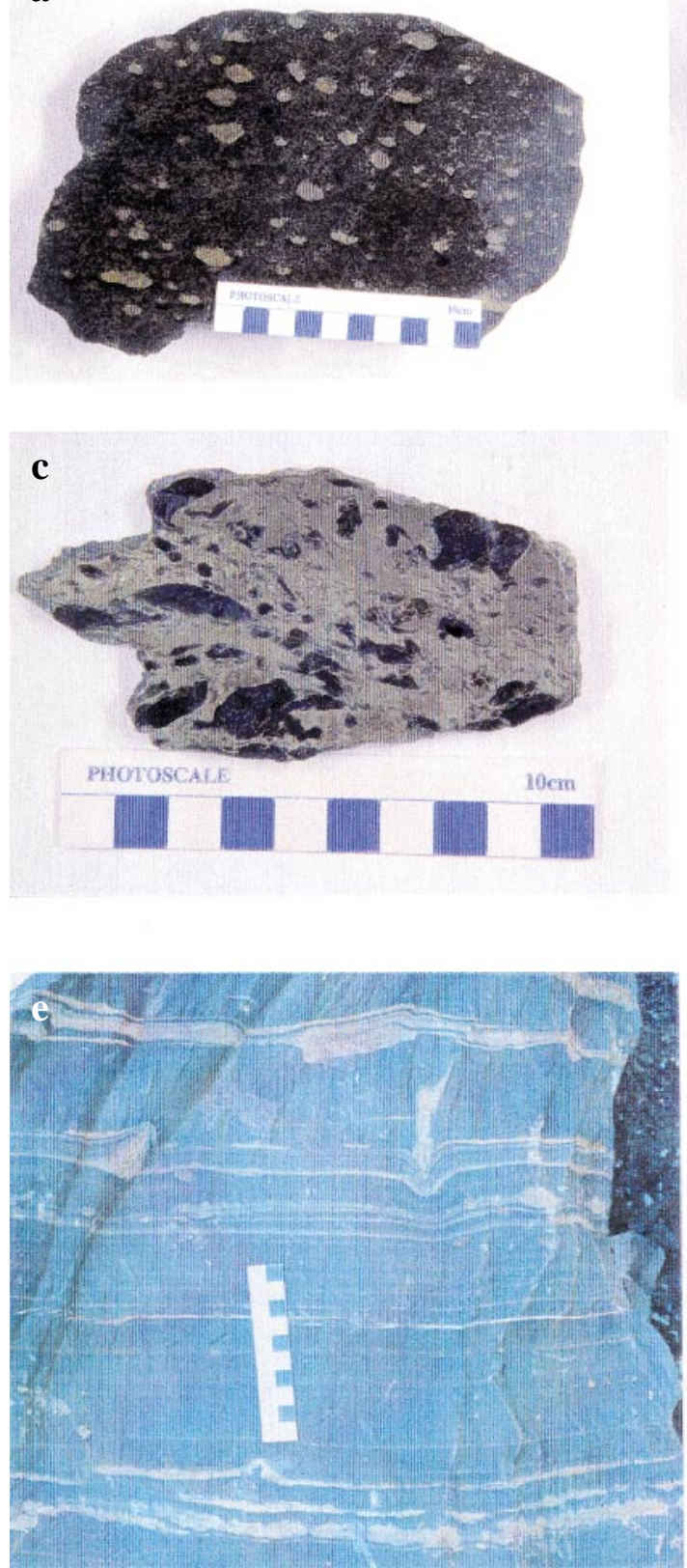

b

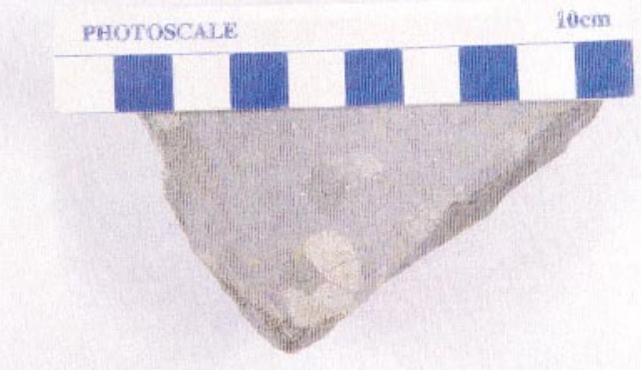

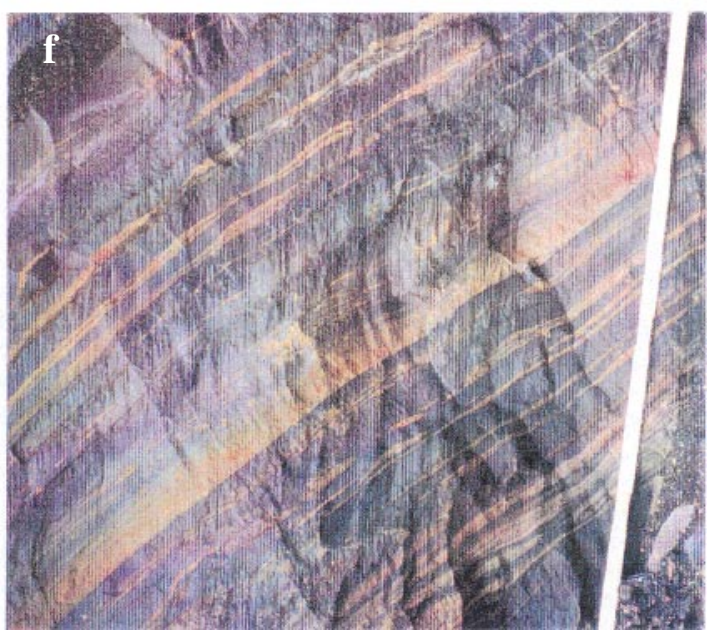

FIG. 2. Photographs of the various types of sulfide ore: a) disseminated sulfide, both globular and interstitial, b) massive sulfide, c) breccia-matrix sulfide, d) vein sulfides, e) thinly bedded organic-carbon-rich mudstone with diagenetic pyrite in layers and catagenic pyrite along the S2 cleavage, and f) black schist (scale: $45 \mathrm{~cm}$ ). 


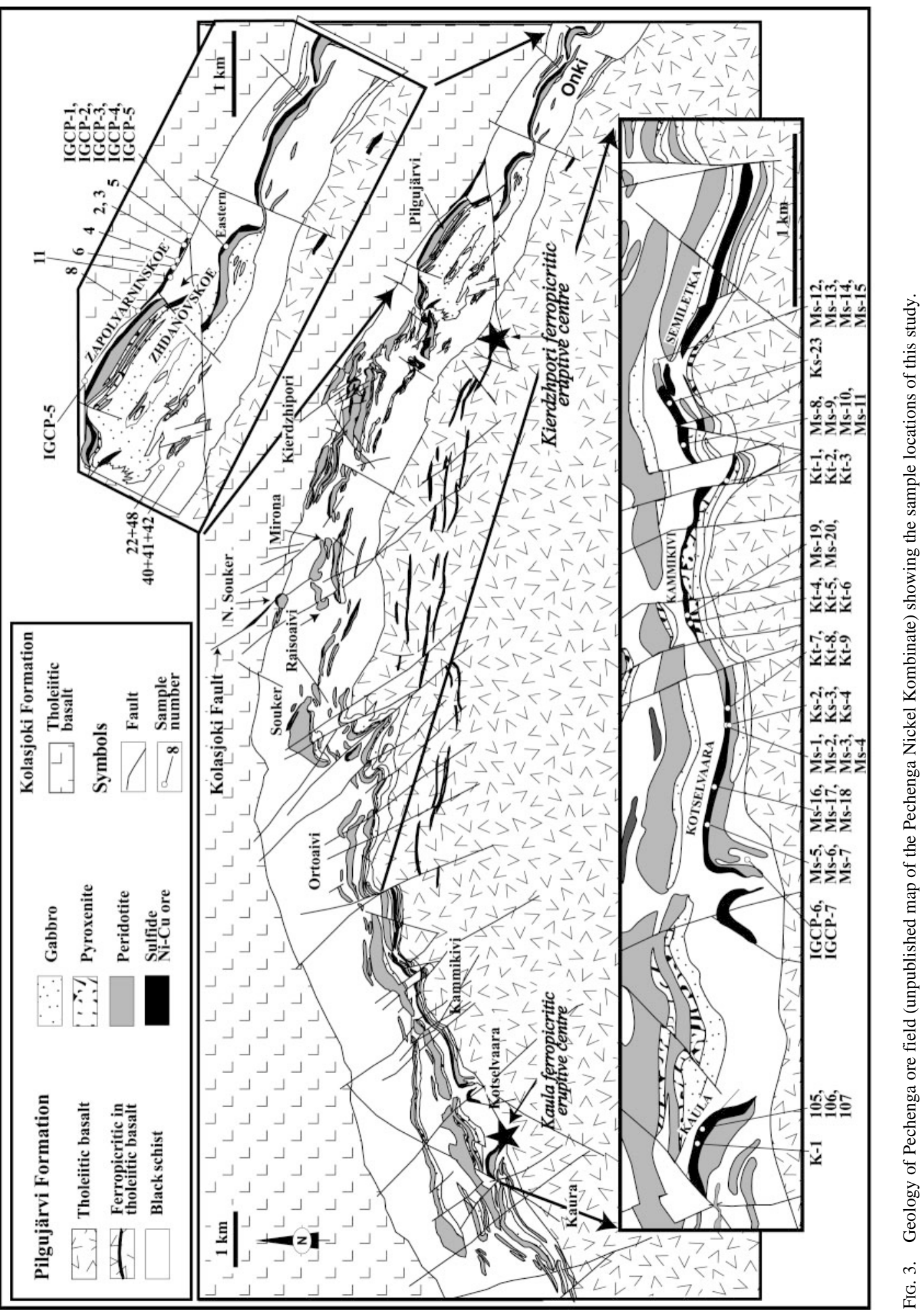


deposits. It is the thickest sedimentary formation in the Group and consists of sulfide-rich black schists (Member A and B, Melezhik et al. 1995) and ultramafic tuffs (Lammas Member or Member C). Basaltic tuffs are sporadically developed throughout the sequence. The formation was deposited in a non-euxinic basin formed during the transition from an intercontinental to an oceanic rift setting.

Numerous ultramafic bodies of both intrusive and effusive origins have been described in the Pechenga Belt (e.g., Zak et al. 1982, Skuf'in \& Fedotov 1989, Hanski \& Smol'kin 1989, Smol'kin 1992). The intrusions are referred to as gabbro-wehrlites (e.g., Smol'kin 1977); the flows have been termed "ferropicrites" (Hanski \& Smol'kin 1989). The ferropicrite flows are weakly differentiated, and the intrusions are well-differentiated gabbro-wehrlite bodies; both occur discordantly and subconcordantly in the sediments of the Pilgujärvi Formation (Fig. 3). The ferropicrite flows are observed intercalated with the Pilgujärvi sedimentary and volcanic rocks. More than 226 differentiated ultramafic-mafic bodies have been counted within the Pilgujärvi sediments; 25 of these contain Ni-Cu deposits of economic interest, and 68 are classified as "NiCu-bearing". The remaining 113 were described as "barren" (Zak et al. 1982), although several are now known host to Ni-Cu sulfides. Thicknesses of the ultramafic bodies range from 5 to $250 \mathrm{~m}$, except for the 466m-thick Pilgujärvi intrusion, and strike lengths range from $100 \mathrm{~m}$ to $6.5 \mathrm{~km}$ (Zak et al. 1982).

The ultramafic bodies containing economic ores are confined within the structure identified as the Western Rift Graben (Fig. 1b) and bounded by long-lived syndepositional faults (Melezhik et al. 1994). The restriction of the ores to the graben indicates that oreforming processes were controlled by paleotectonic setting. Two ferropicritic eruptive centers developed within the Pilgujärvi Formation sediments (Fig. 3), one on the western side of the graben (Kaula), and one on the eastern side (Kierdzhipori). Numerous ferropicritic flows occur in the overlying volcanic units. The ultramafic bodies may also be divided into an eastern and western group. The eastern group consists of Onki, Pilgujärvi, Kierdzhipori, Mirona, Raisoajvi and Souker bodies, and the western group consists of Kaula, Kotsel'vaara, Kammikivi and Semiletka (Fig. 3). The eastern group is located at a lower stratigraphic level of the Pilgujärvi sedimentary sequence than the western group.

\section{Synthesis of Existing IdeAs and DeVelopment of an Overall Model}

There has been extensive work on the geology of the deposits. The findings have been compiled by Gorbunov et al. (1985) and Green \& Melezhik (1999). A summary of the ideas developed to date follows. Most authors interpret the disseminated and massive sulfides as having segregated from an ultramafic magma, and the brec- cia-matrix sulfides and vein ores, as having formed by the remobilization of the massive ore during deformation (Gorbunov et al. 1985, Brugmann et al. 2000, Melezhik et al. 1994, Abzalov \& Both 1997). Hanski (1992) showed, on the basis of the silicate geochemistry of the sulfide-bearing rocks, that these could have formed from a magma similar in composition to the ferropicritic flows. He concluded that the closest modern equivalent to the ferropicrites, in terms of incompatible elements, are ocean-island basalts, and suggested that the ferropicrites were derived from Fe-rich lower mantle, possibly generated from a mantle plume.

The question of whether sulfide saturation was provoked by assimilation of the country rock has caused much controversy; see Green \& Melezhik (1999) for a full discussion. Sulfur isotopes from the eastern ultramafic bodies have positive $\delta^{34} S$ values, suggesting that the $\mathrm{S}$ was derived from the country rocks (Grinenko \& Smol'kin 1991, Hanski 1992, Abzalov \& Both 1997). However, the S-isotope composition of sulfides from the western deposits are close to mantle values, and have been interpreted to indicate that most of the $S$ is of mantle origin (Hanski 1992, Abzalov \& Both 1997). Rhenium-osmium isotopic data from Pilgujärvi and Kammikivi are interpreted to indicate that contamination by crust occurred (Walker et al. 1997). Melezhik et al. $(1994,1998)$ noted the apparent contradictory evidence for the source of $\mathrm{S}$, but showed that the $\delta^{34} \mathrm{~S}$ of the sediments evolves from $-1.2 \%$ (i.e., close to mantle values) in the synsedimentary stage of formation of the sulfides to $+9 \%$ in the late stages of diagenesis (Fig. 4). Melezhik et al. (1998) suggested that the western deposits assimilated mainly unconsolidated sediments with synsedimentary and early diagenetic sulfides, and thus their $\mathrm{S}$ isotopic signature is around 0 . In contrast, the high $\delta^{34} \mathrm{~S}$ values of the eastern deposits are consistent with an emplacement into already consolidated and diagenetically modified sediments, and consequently the magma assimilated $S$ with strongly positive $\delta^{34} \mathrm{~S}$.

Historically, all of the ore-bearing bodies were interpreted as intrusions and referred to as gabbro-wehrlite (Gorbunov et al. 1985). However, a number of features suggest that the western bodies are flows, or possibly one continuous flow, with the feeder zone near the eruptive center at Kaula and an eastward direction of flow to include the Kotsel'vaara, Kammikivi and Semiletka deposits (Green \& Melezhik 1999). a) The western bodies occur high in the sedimentary sequence, close to the upper sedimentary-volcanic boundary, and are intercalated with ferropicrite tuffs and flows. b) The western bodies are thin $(<100 \mathrm{~m})$, consisting mainly of peridotite and pyroxenite with minor gabbro (Fig. 3), implying relatively rapid cooling. c) The $S$ isotopic signature of the western deposits is close to a mantle value and, as discussed above, implies that the magma has assimilated unconsolidated sediments, which would be more likely to occur if the bodies represent flows. In contrast, the Pilgujärvi body, which hosts the three $\mathrm{Ni}$ deposits of 


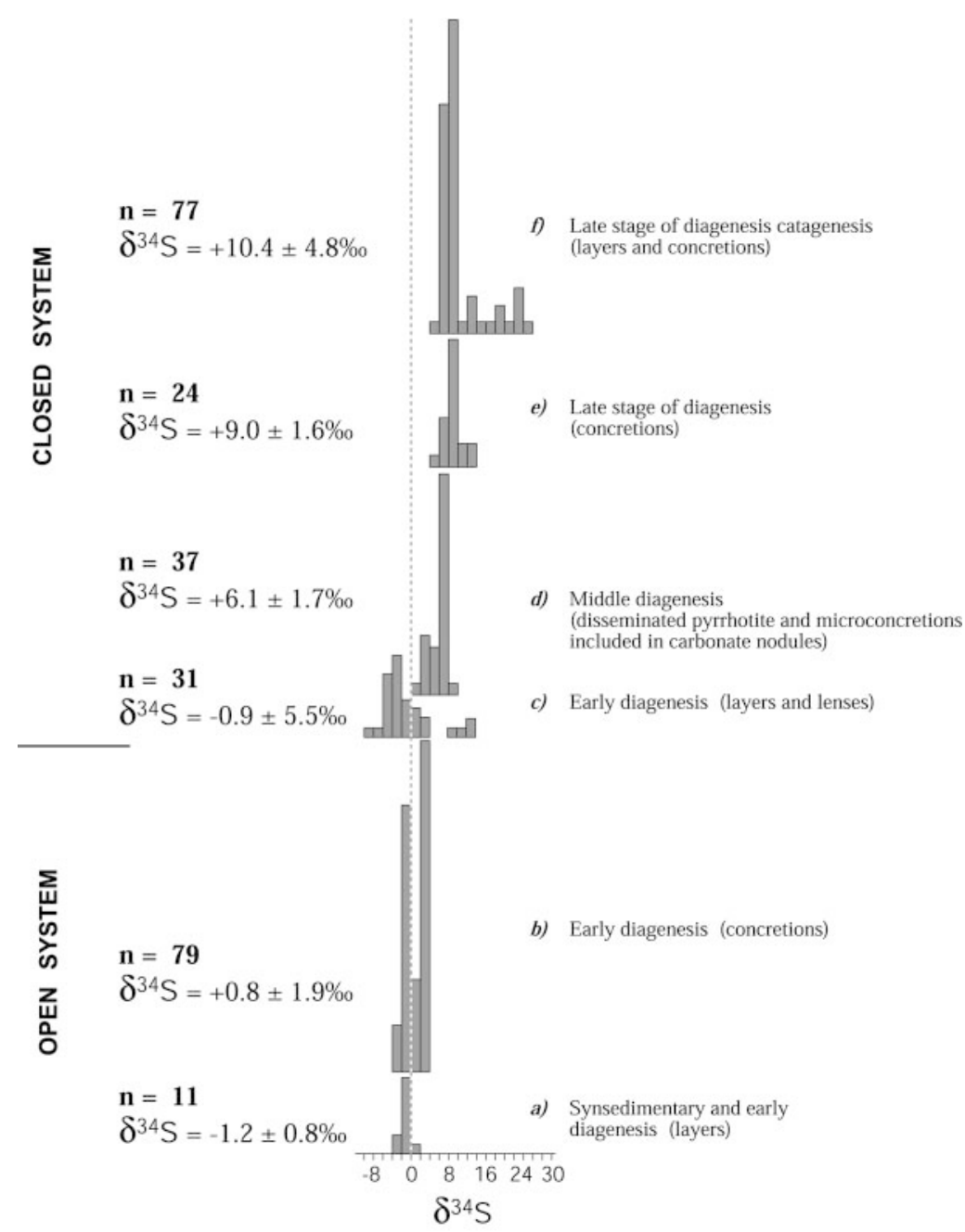

FIG. 4. Sulfur isotopes of the sediments. Source: Melezhik et al. (1998).

the eastern end of the ore field (Zhdanovskoe, Zapolyarninskoe and Eastern), is close to the base of the sedimentary sequence (Fig. 3). It is thick $(\sim 500 \mathrm{~m})$ and well differentiated, with a large component of gabbro (Fig. 3), implying slow cooling. The $\mathrm{S}$ isotopes imply that it was emplaced into, or onto, consolidated sediments. These features are consistent with an intrusive emplacement, although they do not rule out the possibility of emplacement as a very thick, ponded flow.

The abundances of noble metals in mineralized samples have been reported for 14 samples from Kotsel'vaara and Pilgujärvi by Abzalov \& Both (1997), who concluded that 1) the $P G E$ were collected by the sulfides during segregation, 2) the ratio of $\mathrm{Ni}$ and $\mathrm{Cu}$ to $P G E$ is much higher than a mantle value, and 3) Au has been redistributed in deformed samples. Brugmann et al. (2000) showed graphs of results for approximately a dozen mineralized samples. They also concluded that the $P G E$ have been collected by magmatic sulfides and that the low $\mathrm{Pd} / \mathrm{Ir}$ values of the sulfide-bearing samples are consistent with segregation of the sulfides from an ultramafic magma, such as a ferropicritic magma.

All of the above information suggests a model in which the Pechenga ferropicrites, derived from a plume stem, were emplaced into the failed arm of an aulacogen, with the western bodies erupted onto sediments and the eastern bodies intruded into the sediments (Fig. 5). Sulfur was introduced into the magma by contamination and formed igneous sulfides, which then collected the metals. Where these sulfides became sufficiently concentrated, the orebodies formed. 


\section{WESTERN GRABEN}

$-W$

FAILED ARM SETTING OF PECHENGA PICRITES AFTER SUBSIDENCE OF PLUME RELATED THERMAL UPLIFT

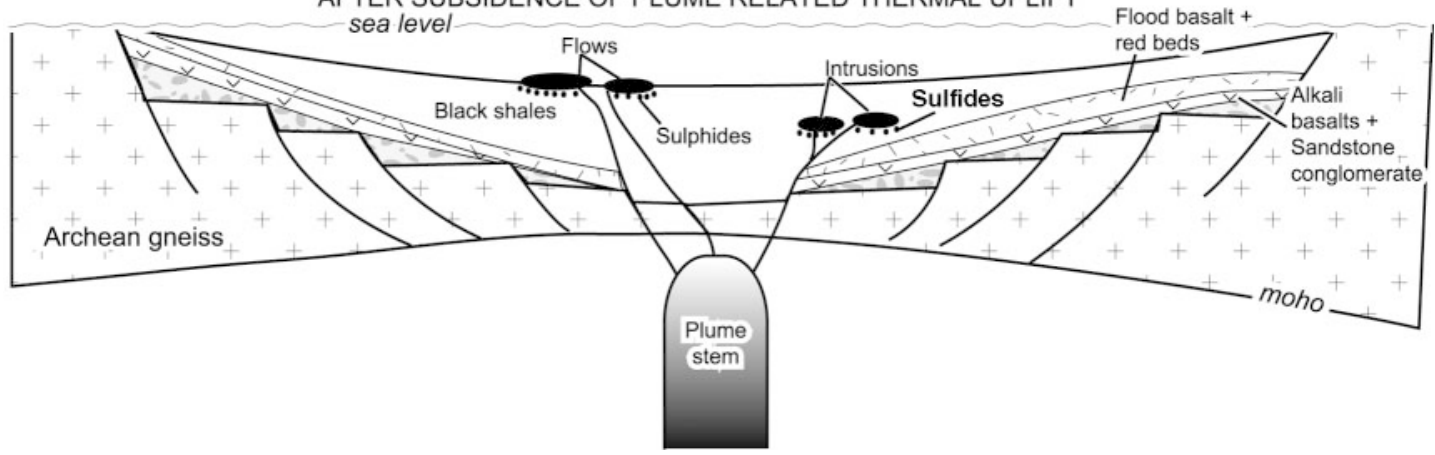

FIG. 5. Model for the tectonic setting of the Pechenga area at the time of emplacement of the ferropicrites, showing a cross section through the Western Graben.

\section{SAMPLING}

Sixty-nine samples have been collected from the underground operations and the open pits. Samples from the eastern part of the ore field are derived from two different settings. Four samples represent the most common, low-grade, disseminated sulfides in the Pilgujärvi intrusion peridotites from the Eastern deposit. Six samples were collected from the Zapolyarninskoe deposit, which is located in a tectonic zone within the black-schist country rock beneath the central part of the Pilgujärvi intrusion (Fig. 3).

Within the western part of the ore field, samples have mainly been obtained from underground mines through a series of traverses across the contact ore from footwall to hanging wall. The traverses are spaced 60 to 780 $\mathrm{m}$ apart and are $300 \mathrm{~m}$ in length on average (Fig. 3). The aims of these traverses were to study a) the chemical differences among major types of ore (i.e., massive, breccia-matrix and disseminated) and b) chemical variations in orebodies along strike, away from the inferred eruptive center.

\section{THE Sulfides}

The largest deposits at Pechenga (Zapolyarninskoe and Zhdanovskoe) occur in the eastern part of the belt, within the Pilgujärvi intrusion, near the Kierdzhipori Eruptive Center (Fig. 3). These deposits contain largely disseminated sulfides. The Kaula, Kotselvaara, Kammikivi, and Semiletka deposits in the west contain mainly massive and breccia-matrix sulfides, but are much smaller in tonnage than those associated with the Pilgujärvi intrusion.

The disseminated sulfides occur toward the base of the intrusions and flows, and in some cases they overlie massive or breccia-matrix sulfides. They grade upward into weakly mineralized peridotite or serpentinite and further upward into non-mineralized ultramafic and mafic rocks. The zones containing the sulfides are up to $100 \mathrm{~m}$ in thickness. In the undeformed rocks, the host to the disseminated sulfides is an olivine cumulate. The disseminated sulfides (Fig. 2a) occur as globules $1-5 \mathrm{~cm}$ in diameter or interstitially to polyhedral olivine (1-3 $\mathrm{mm}$ ), which is replaced by serpentine, chlorite and, in some cases, talc and dolomite (Lagueux 1999). Small grains of euhedral chromite are present between the olivine grains in some samples. The sulfides consist of intergrowths of pyrrhotite, pentlandite and chalcopyrite, and contain 5 to $10 \%$ magnetite (Lagueux 1999). In the deformed rocks, the cumulate texture has been lost, and the host rock to the disseminated sulfides is an ultramafic schist or serpentinite. The sulfides there occur as streaks in the rock. The whole-rock grade of these ores is $1-1.5 \mathrm{wt} \% \mathrm{Ni}$ (Gorbunov et al. 1985; Table 2 of this paper).

The massive and breccia-matrix sulfides form layers 0.5 to $11 \mathrm{~m}$ thick at the bases of the flows and intrusions. These layers continue subparallel to the contact but enclosed within the country rock for up to a kilometer (Fig. 3). The massive sulfides (Fig. 2b) are composed of $60-70 \%$ pyrrhotite, $20-30 \%$ pentlandite, 3-10\% chalcopyrite, and 5-10\% magnetite (Lagueux 1999). Distler et al. (1990) reported the presence of minor pyrite, violarite, sphalerite, bornite, cubanite, mackinawite, valleriite and platinum-group minerals $(P G M)$. The whole-rock grade of these ores is 10 to $12 \mathrm{wt} \% \mathrm{Ni}$ and 1 to $13 \mathrm{wt} \% \mathrm{Cu}$ (Gorbunov et al. 1985; Table 2).

Breccia-matrix sulfides (Fig. 2c) occur both in the footwall and the hanging wall of massive orebodies. The breccia matrix sulfides are composed of rounded fragments of serpentinite, black schist, chert and carbonate 
TABLE 1. LTTHOPHILE FI.EMENT CONCENTRA'IONS N THE PECHENGA ROCKS

\begin{tabular}{|c|c|c|c|c|c|c|c|c|c|c|c|c|}
\hline \multirow[b]{2}{*}{$\begin{array}{l}\text { Locality } \\
n\end{array}$} & \multirow{2}{*}{\multicolumn{2}{|c|}{$\begin{array}{c}\text { Fetropicite } \\
\text { Tuffy Lower } \\
\\
\text { Chill } \\
\text { West } \\
2^{5} \\
\text { East }\end{array}$}} & \multirow{2}{*}{\multicolumn{2}{|c|}{ 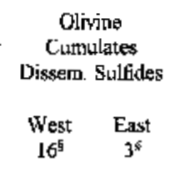 }} & \multicolumn{2}{|c|}{$\begin{array}{c}\text { B]ack Schists } \\
\text { with pyrite }\end{array}$} & \multirow{2}{*}{$\begin{array}{l}\text { Pyrite- } \\
\text { rich } \\
\text { Conglom. } \\
\text { East } \\
1\end{array}$} & \multicolumn{2}{|c|}{$\begin{array}{l}\text { Brectid-Matrix } \\
\text { Sulfides with } \\
\text { Sedim. Fx }\end{array}$} & \multicolumn{2}{|c|}{$\begin{array}{l}\text { Brecia-matrix } \\
\text { Sultides with } \\
\text { Ol. Camil. Fx }\end{array}$} & \multirow{2}{*}{$\begin{array}{r}\text { Vein } \\
\text { tich } \\
\text { in Cop } \\
\text { East } \\
1\end{array}$} \\
\hline & & & & & $\begin{array}{c}\text { West } \\
5^{5}\end{array}$ & $\begin{array}{c}\text { Enst } \\
2^{6}\end{array}$ & & West & $\begin{array}{c}\text { East } \\
1\end{array}$ & $\begin{array}{c}\text { West } \\
10^{5}\end{array}$ & $\begin{array}{c}\text { East } \\
1\end{array}$ & \\
\hline $\mathrm{SHO}_{2}, \mathrm{~W} \%$ & 44,35 & 40.52 & 34.93 & 30.47 & 53,69 & $3 \xi .14$ & 77.09 & 15.75 & 15.77 & 23.53 & 20.02 & 8.73 \\
\hline $\mathrm{TiQ}_{1}$ & 2.54 & 1.59 & 0.71 & 0.57 & 1.30 & 1.25 & 0.18 & 0.50 & 1.00 & 0.41 & 0.18 & 0.20 \\
\hline $\mathrm{N}_{2} \mathrm{O}_{1}$ & 6.88 & 5.33 & 210 & 1.68 & 10.79 & 13.55 & 1.59 & 7.22 & 6.58 & 1.73 & 2.43 & 1.78 \\
\hline FeO" & 16.99 & 16,39 & 8.14 & 13.96 & 985 & 13.92 & 0,39 & 5.02 & y.tog & 725 & 0.01 & 7,78 \\
\hline $\mathrm{MgO}$ & 16,82 & 18.73 & 2526 & 3039 & 5.13 & 8.29 & 0.82 & 7.10 & 4.87 & 20.54 & 15.70 & 9.91 \\
\hline $\mathrm{CaO}$ & 10.22 & 9.27 & 1,25 & 0.56 & 2,41 & 3.73 & 15.44 & 3.05 & 1,07 & 1.6 .3 & 267 & 115 \\
\hline $\mathrm{Na}_{2} \mathrm{O}$ & 0.13 & 0.50 & 0.03 & 004 & 0.58 & 0.67 & 030 & 0.07 & 0.09 & 0,01 & 0.04 & 0,02 \\
\hline $\mathbf{K}-0$ & 0.42 & 0.07 & 0,02 & 0.03 & 0.96 & 0.36 & 047 & 0.14 & 018 & 0.02 & 0.05 & 0.05 \\
\hline I.a ppm & 39.25 & 1581 & 6.38 & 5.35 & 14,50 & 11.99 & 12.85 & 5.75 & 2.34 & 3.24 & 1.70 & 2.10 \\
\hline $\mathrm{Ce}$ & 47.8 & 37.0 & 13.4 & 12.5 & 29.4 & 18.5 & 19,9 & 11.5 & 3.1 & 6.1 & 2.1 & 2.4 \\
\hline $\mathrm{Nd}$ & 26.0 & 17,4 & 8.4 & 6.6 & 15.2 & 10.6 & 9.0 & 6.5 & $\approx$ & 3.6 & 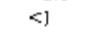 & 3.5 \\
\hline $\mathbf{S}_{10}$ & 6.44 & 4,86 & 1.98 & 1.58 & 3.48 & 299 & 2.16 & 1.33 & 0,61 & 0.91 & 0,42 & 0.39 \\
\hline Eu & 2,64 & 181 & 0.65 & 0.53 & 1.07 & 0.87 & 0.58 & 0.51 & 0.010 & 0.31 & 0.13 & 0.14 \\
\hline $\mathrm{Tb}$ & 0.92 & 0.52 & 0.22 & 0.13 & 0.30 & 0.16 & 0.3 & 020 & 0.1 & 0,17 & $<0.1$ & 0.1 \\
\hline $\mathrm{Yb}$ & 1.42 & 0.97 & 0.42 & 0.36 & 1.21 & 1.02 & 2.00 & 0.5 & 0.1 & 0,22 & $\quad 0.1$ & 0.10 \\
\hline Lit & 0.22 & 0.17 & 0.07 & 0.05 & 0.22 & 0.17 & 0.33 & 0.09 & 0.05 & 0,04 & $\quad 0.05$ & $\$ 0.05$ \\
\hline$B a$ & 132 & $<30$ & 30 & 30 & 257 & 144 & 40 & 75 & 74 & 30 & 30 & $=30$ \\
\hline $\mathrm{Cr}$ & 1408 & 1876 & 2348 & 2425 & 279 & 450 & 39 & 516 & 848 & 3.325 & 664 & 374 \\
\hline$C s$ & 10.7 & 0.9 & 0.96 & 0,58 & 1.46 & 2.11 & 0.5 & 0.98 & 1.7 & 0.46 & $\quad 0.2$ & $\infty .1$ \\
\hline HE & 4.24 & 2.9 & 1.12 & 0.88 & 3.94 & 1.90 & 1.0 & 1.01 & 60.2 & 0.66 & $\infty 2$ & 0.5 \\
\hline kx & 39 & 1.7 & 8 & 8 & 43 & 20 & 21 & 28 & 15 & 10 & 5 & $\therefore 5$ \\
\hline $5 c$ & 31 & 26 & 12 & 11 & 17 & 18 & 4 & 7 & 4 & 8 & 3 & 3 \\
\hline $\mathrm{Ta}$ & 1.49 & 1.1 & 0.33 & 0.33 & 0.73 & 0.64 & $\approx 0.1$ & 0.22 & $=0.1$ & 0.30 & $<0.1$ & 80.1 \\
\hline Th & 2.52 & 1.7 & 0.70 & 0.61 & 3.68 & 2,60 & 0.9 & 51 & 1.3 & 0.42 & 1.2 & 0.4 \\
\hline $\mathrm{L}^{\circ}$ & 0.90 & 0.3 & 0.23 & 0.20 & 5.08 & 3.08 & 24 & 1.38 & 0.1 & 0.31 & $<0.2$ & 0.1 \\
\hline$\forall$ & 762 & 296 & 164 & 121 & 407 & 296 & 60 & 197 & 126 & 116 & 89 & 73 \\
\hline U/Th & 0.36 & 0.20 & 0.29 & 0.33 & 1.38 & 1.18 & 2.70 & $0.9]$ & 0.11 & 0.74 & $4 \quad 0.17$ & 0.25 \\
\hline 'hi'Ta & 1,69 & 1.61 & 2.43 & 1.86 & 5.01 & 4.] & $\times 8.8$ & 7.00 & $=13$ & 2.14 & $=12$ & $\therefore 4$ \\
\hline $\mathrm{K}_{2} \mathrm{O} \mathrm{iSm}$ & 648 & 141 & 120 & 192 & 2758 & 1190 & 2179 & 1054 & 2911 & 218 & 1493 & 1163 \\
\hline Yb/Sin & 0.22 & 0.20 & 0.21 & 0.23 & 0.35 & 0.34 & 0.93 & 0.38 & $>6.1$ & 0.24 & $1 \quad 80.24$ & 0.26 \\
\hline SuiLı & 144 & 153 & $I 78$ & 196 & 77 & 104 & 11 & 77 & $37 R$ & 164 & $>60$ & $>60$ \\
\hline
\end{tabular}

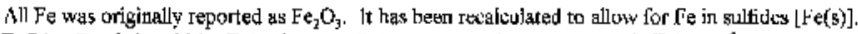

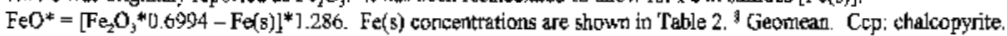

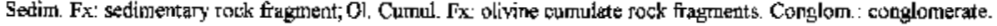

The complete dataset is ayalable upon request.

in a sulfide matrix identical to the massive ore (Lagueux 1999). Whole-rock grades average 3 to $9 \mathrm{wt} \% \mathrm{Ni}$ and 4 to $6 \mathrm{wt} \% \mathrm{Cu}$ (Zak et al. 1982, Gorbunov et al. 1985; Table 2).

The black-schist-hosted $\mathrm{Cu}$ stringer- or vein-type sulfide ore (Fig. 2d) is subordinate in volume and predominantly developed close to the footwall of massive or breccia-matrix sulfides, and locally has been found further away, in tectonized zones. The ores are dominated by chalcopyrite; whole-rock $\mathrm{Ni}$ and $\mathrm{Cu}$ values vary from 0.1 to $2 \mathrm{wt} \% \mathrm{Ni}$ and contain up to $10 \mathrm{wt} \% \mathrm{Cu}$ (Gorbunov et al. 1985; Table 2).

In many cases, the black schist in contact with the ultramafic bodies is bleached. The bleached zones range from a few tens of centimeters to a few meters in width (field observations of VM) and are characterized by the complete loss of organic matter and a substantial loss of sulfides. The black schist contain 2 to $20 \%$ pyrite. This pyrite has a number of forms: there are layers and concretions of fine-grained synsedimentary and early diagenetic pyrite; there are also coarse-grained, latediagenetic concretions and catagenetic pyrite (Fig. 2e).

All of the orebodies contain the four types of $\mathrm{Ni}$ sulfide mineralization. The average nickel and copper concentrations gradually increase from the eastern group of deposits toward the western ones, because the western bodies contain more massive sulfides. But as can be seen from the Ni/S values in Table 1 , the grade in $100 \%$ sulfide does not change systematically.

\section{GEOCHEMISTRY}

\section{Methods}

In Table 1, the values for the major oxides (except $\mathrm{Na}_{2} \mathrm{O}$ ) and the elements $\mathrm{Ni}$ and $\mathrm{V}$ (X-ray fluorescence), 
$\mathrm{Cu}$ (atomic absorption) and $\mathrm{S}$ (Leco titration) were determined at the Geological Survey of Norway. Concentrations of all other elements, except for the $P G E$, were determined by instrumental neutron activation (INAA) on $2 \mathrm{~g}$ of rock powder at the Université du Québec à Chicoutimi (UQAC), using the method outlined in Bédard \& Barnes (1990). The concentration of some elements ( $\mathrm{Fe}, \mathrm{Na}, \mathrm{Cr}, \mathrm{Co}, \mathrm{Ni}$ ) was determined both by $\mathrm{XRF}$ and INAA. Comparison between the two sets of results generally indicates less than $10 \%$ difference. The proportions of $\mathrm{MnO}$ and $\mathrm{P}_{2} \mathrm{O}_{5}$ were not determined in these rocks, but have been determined in similar rocks (Melezhik et al. 1994) and are generally present at less than $0.5 \%$. Loss on ignition (LOI) could not be reliably determined in these rocks because FeS is partially converted to $\mathrm{Fe}_{2} \mathrm{O}_{3}$ in the process, and thus the determined LOI does not represent $\mathrm{H}_{2} \mathrm{O}$ and $\mathrm{CO}_{2}$ loss. An estimate of the true LOI may be made if it is assumed that concentrations of all the elements of significance have been determined. Then LOI is 100 minus the sum of the major oxides, $\mathrm{S}, \mathrm{Ni}$ and $\mathrm{Cu}$. By this estimation, LOI in these rocks varies from close to zero in many of the mineral separates to $20 \%$ in the carbonate-rich samples.

Concentrations of the $P G E$ were determined by INAA at Chicoutimi after a fire assay using a Ni-sulfide bead collection on $50 \mathrm{~g}$ of sample. The precision based on the relative standard deviation is estimated to be $5-10 \%$ for Ir, Rh, Pt and Pd, and $10-20 \%$ for Os and $\mathrm{Ru}$. For the mineral separates, only $5 \mathrm{~g}$ of material was available, and as the $P G E$ are only present at the ppb level, these results may be influenced by the nugget effect. Gold values from the fire assay were systematically an order of magnitude lower than those obtained by INAA on the rock powder. This is attributed to $\mathrm{Au}$ lost in the dissolution step of the fire-assay procedure; thus the $\mathrm{Au}$ values reported here are those from the determinations on the whole-rock powder and not the fire assay. Agreement between Ir values from the fire assay and whole-rock determinations on powder was within $90 \%$ for samples with greater than $5 \mathrm{ppb}$ Ir, indicating good recovery for this element.

Sulfide minerals were acquired for isotope analyses by heavy-liquid separation followed by magnetic and electromagnetic techniques. Hand-picking of grains was also used where necessary. The $\delta^{34} \mathrm{~S}$ was measured on 89 sulfide samples on VG ISOGAS SIRA II mass spectrometer at the Scottish Universities Environmental Research Center. The precision of $\delta^{34} \mathrm{~S}$ measurements was $\pm 0.2 \%$ o $(1 \sigma)$.

\section{Lithophile elements}

Hanski (1992) has shown that both the intrusions and flows that host the disseminated sulfides were derived from a magma of similar composition, which he called ferropicritic, but much richer in $\mathrm{FeO}$ than a normal picritic magma. In our study, two tuffs from the Kotsel'vaara mine and the lower marginal chill from
Pilgujärvi are the closest approximation we have to liquid compositions. These samples contain 17-20\% MgO, and are rich in $\mathrm{Cr}, \mathrm{Ni}$, and $\mathrm{Co}$ (Table 1). The tuff and chilled margin are unusually enriched in Fe, large-ion lithophile elements ( $L I L E)$, light rare-earth elements (LREE) and high field-strength elements (HFSE) (Table 1; Fig. 6a), and therefore show the same characteristics as documented by Hanski in the ferropicritic flows. An exception to the enrichment of LILE is $\mathrm{K}$, which shows a negative anomaly on the mantle-normalized plot (Fig. 6a). Compared with the Cape Smith picrites of northern Quebec (which are similar in age, host similar Ni-sulfide deposits and occur in a similar tectonic setting: Barnes et al. 1992), the Pechenga ferropicrites contain similar levels of $\mathrm{MgO}, \mathrm{Cr}, \mathrm{Ni}, \mathrm{Co}, \mathrm{Zn}, \mathrm{Cu}, \mathrm{Au}$, $\mathrm{Sc}$ and the heavy rare-earth elements (HREE), but contain 10 times as much LILE, LREE, HFSE, As and Sb (Table 3 of Barnes et al. 1992). The Pechenga suite shows a depletion in $\mathrm{Al}$ relative to the HREE, Sc and V on a mantle-normalized plot (Fig. 6a). As noted by Hanski (1992), the abundances of incompatible elements in the ferropicrite resemble those of an ocean island basalt (OIB on Fig. 6a), but the Pechenga ferropicrites are much richer in compatible elements and Fe than OIB. Hanski (1992) attributed the unusual geochemistry of the Pechenga ferropicrites to melting of an $\mathrm{Fe}$-, LILE-, and LREE-enriched mantle by a plume.

Contamination of the ferropicritic magma by black schists of the Pilgujärvi Formation is considered to have induced sulfide saturation; thus it is important to examine the differences in composition between the schists and the ferropicrites. These differences can then be used in order to examine the sulfide-bearing rocks for signs of contamination. A remarkable feature of the schists is their close similarity in incompatible trace-element concentrations with the tuffs and chilled margin. The mantle-normalized trace-element patterns are similar both in shape and level for most elements (Fig. 6b). This is less surprising if it is remembered that these sediments may have been unconsolidated at the time the ferropicrite was emplaced and that a large component of the schist may in fact have been eroded by the ferropicritic magma. Important differences are the positive $\mathrm{U}$ and $\mathrm{K}$ anomalies in the schists. The positive $\mathrm{U}$ anomalies are a feature of black shales worldwide (McKelvey et al. 1955). The schists are also richer in $L I L E, \mathrm{Al}_{2} \mathrm{O}_{3}, \mathrm{~V}$ and the HREE (Table 1, Fig. 6b).

FIG. 6. Plots of mantle-normalized concentration of incompatible elements (normalization values from McDonough \& Sun 1995): a) tuff, lower chilled zone and rocks that host disseminated sulfides. Note the similarity between the shape of the OIB pattern and the Pechenga ferropicrites. b) Sedimentary units; note the positive $\mathrm{U}$ and $\mathrm{K}$ anomalies and general $L I L E$ enrichment compared to the ferropicrite. c) Breccia-matrix sulfides; note the positive $\mathrm{U}$ and $\mathrm{K}$ anomalies. 

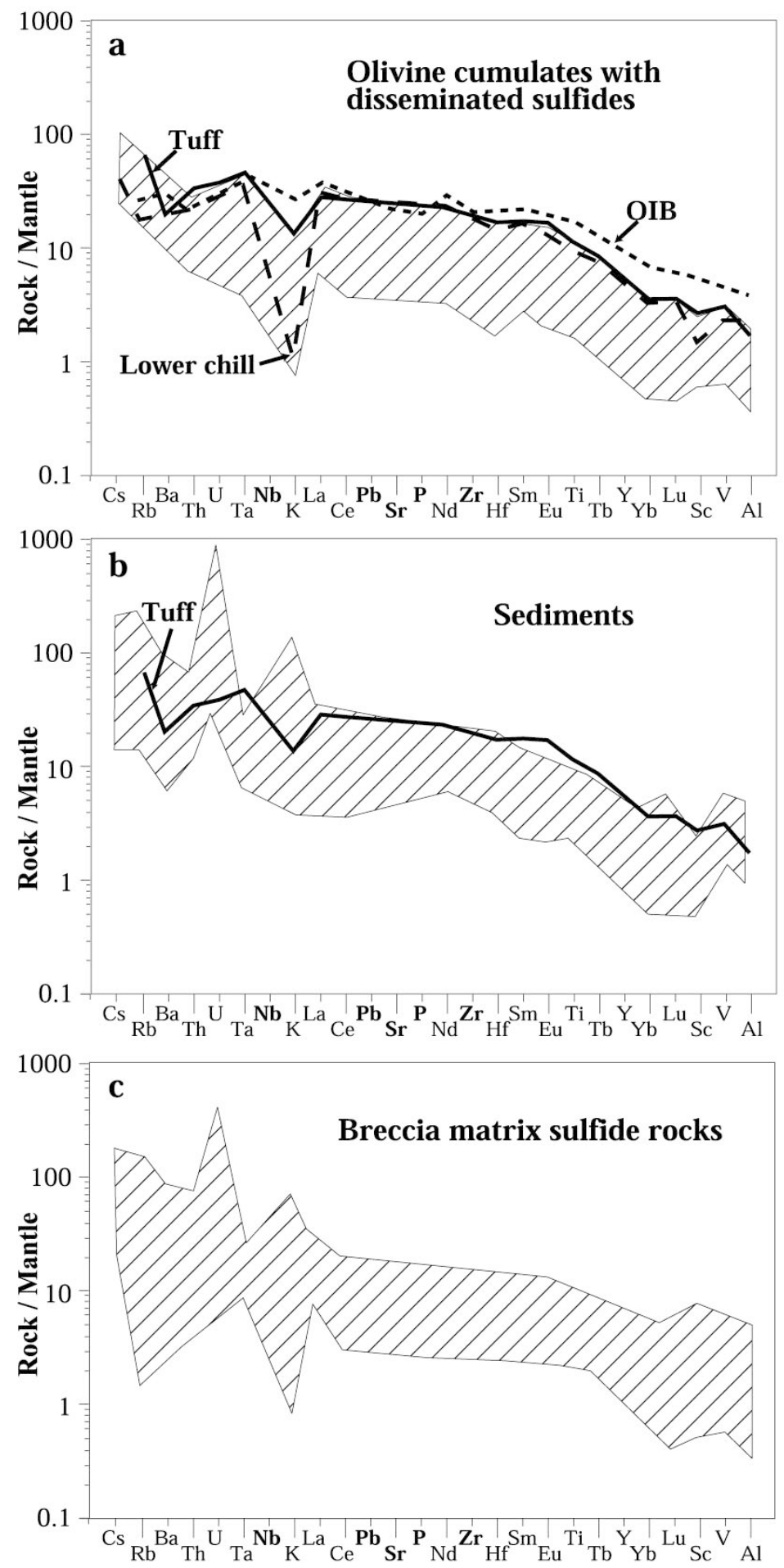
The sulfide-bearing rocks are the olivine cumulates with disseminated sulfides and the breccia. The olivine cumulates have mantle-normalized incompatible element patterns that are slightly lower than, but parallel to, the tuff and lower chilled margin sample (Fig. 6a), and do not appear to show any $\mathrm{U}$ or $\mathrm{K}$ anomalies. Thus the mantle-normalized trace-element patterns suggest that contamination was not significant for the lithophile elements. The breccia-matrix sulfide is considered to be tectonically remobilized massive ore. Several samples contain fragments of black schist and carbonate. In the other samples, the fragments are mainly ultramafic rocks and carbonate. Thus the breccia has been divided into those samples containing visible fragments of sedimentary rocks and those with ultramafic fragments (Table 1). The breccia with fragments of sedimentary rock is richer in LILE, Al, $\mathrm{U}$ and $\mathrm{K}$ (Table 1), and has positive $\mathrm{U}$ and $\mathrm{K}$ anomalies on the mantle-normalized plots (Fig. $6 c)$. But as this is a mechanical mixture of fragments of sedimentary rock and sulfides, it could not have led to the segregation of sulfide liquid at the time the ores were formed.

It is possible that simply examining the fields of the different rock-types on mantle-normalized diagrams is not a sufficiently sensitive technique to show the effects of contamination. The schists contain more LILE, HREE, $\mathrm{Al}$ and $\mathrm{V}$, but less $\mathrm{Sc}$, than the olivine cumulates (Table 1). Thus $\mathrm{U} / \mathrm{Th}, \mathrm{K}_{2} \mathrm{O} / \mathrm{Sm}, \mathrm{Th} / \mathrm{Ta}, H R E E / \mathrm{Sm}$, $\mathrm{Al}_{2} \mathrm{O}_{3} / \mathrm{TiO}_{2}$, and $H R E E / \mathrm{Sc}$ values should be higher in contaminated rocks than in uncomtaminated rocks. A plot of $\mathrm{U} / \mathrm{Th}$ versus $\mathrm{K}_{2} \mathrm{O} / \mathrm{Sm}$ shows this, in broad terms (Fig. 7a). The field of sedimentary rocks lies in the upper right-hand corner, and the ferropicrites and the olivine cumulates that contain the disseminated sulfides plot in the bottom left. The breccia-matrix sulfides plot between the olivine cumulates and the sedimentary rocks. The olivine cumulate with disseminated sulfides does not appear to have significantly higher U/Th and

TABLF 2. CHALCOPHILE ELEMTKT CONCENTRATIONS IN ROCKS AND SULFLE SEPARATES, PECHIINGA, RUSSL

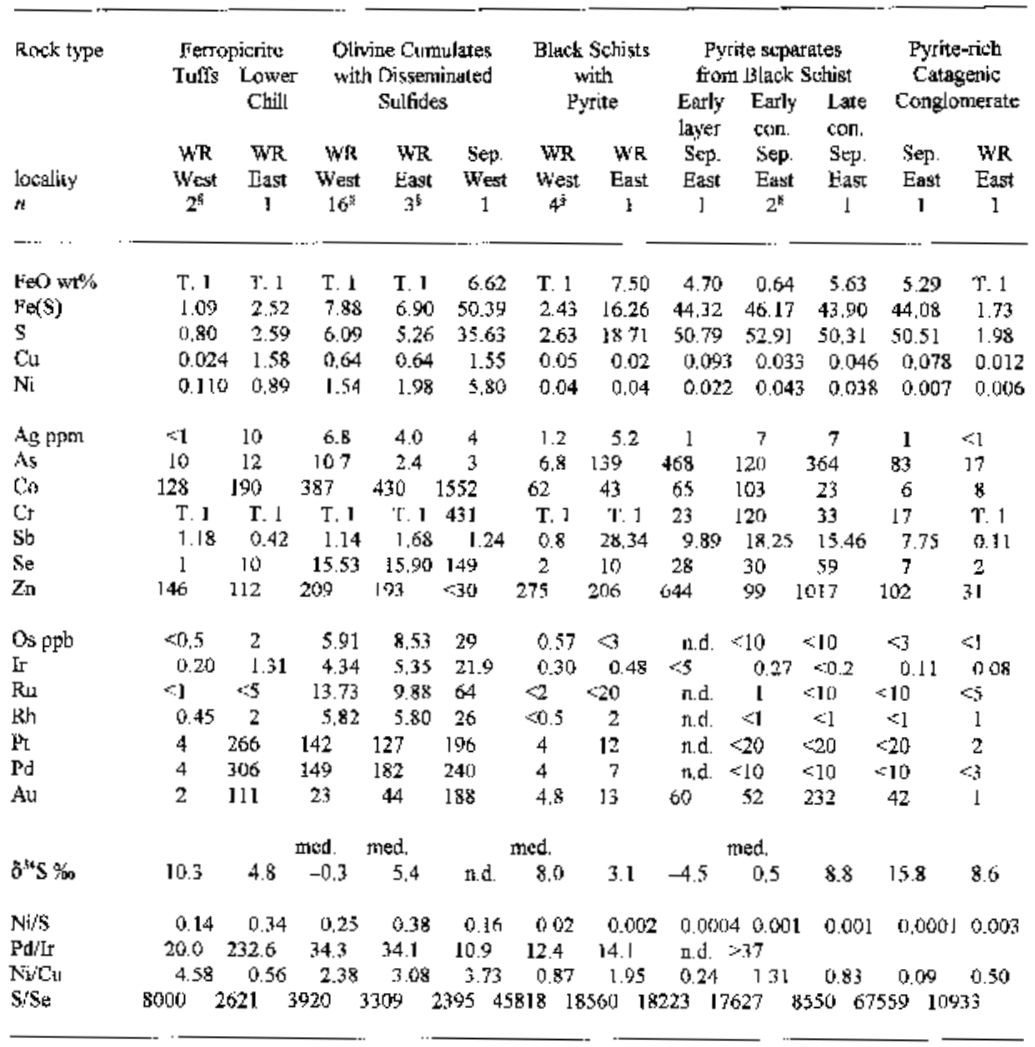

$\mathrm{Fe}(\mathrm{S})$ in the ultramalis rocks $=1.527^{*} \mathrm{~g}-0.6592 *(\mathrm{Cu} \quad 0.02)-0.5285^{4}(\mathrm{Ni} \cdot 0.1)$. nhtich assumes that the sullides congigt of $\mathrm{Po}$, Po and $\mathrm{Ccp}$, and that the silicates contain $0.1 \% \mathrm{Ni}$ and $0.02 \% \mathrm{Cu}$. Gevmean.

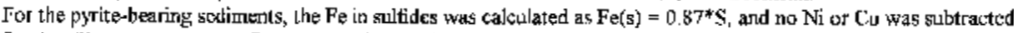
for the silicate compotont. Cont. : conçretion, n.d : not determinet, med.: median, WR: nihole rock, Sep.: scparate, I. 1: Table I. 
$\mathrm{K}_{2} \mathrm{O} / \mathrm{Sm}$ values than the tuff and chilled margin, which suggests that contamination has not occurred. However, $\mathrm{K}$ is mobile, and both $\mathrm{U}$ and $\mathrm{Th}$ are present at close to detection level in the olivine cumulates, such that other sets of inter-element ratios should be considered. Analytical precision for $\mathrm{Sc}, \mathrm{Sm}$ and the $H R E E$ is good; furthermore, these elements are fairly immobile. The sedimentary rocks have higher $\mathrm{Lu} / \mathrm{Sc}_{\mathrm{N}}$ and $\mathrm{Yb} / \mathrm{Sm}_{\mathrm{N}}$ values than the ferropicrite and the olivine cumulates that host the disseminated sulfide (Fig. 7b). The olivine cumulates, the tuffs and the chilled margin plot in a tight cluster separate from the sedimentary rocks. The breccia containing visible fragments of sedimentary rock plots with the sedimentary rocks, but the breccia containing fragments of ultramafic rock plots with the olivine cumulates. Thus here too it seems that the lithophile elements do not indicate evidence for contamination of the ferropicritic magma by the sedimentary material.

Magnesium and $\mathrm{Cr}$ are generally higher in the olivine cumulates containing disseminated sulfides than in the tuffs and chilled margin. These observations are in agreement with petrographic findings, which indicate that the disseminated sulfides are hosted by olivine cumulates that contain minor chromite. On plots of concentrations of incompatible elements versus $\mathrm{MgO}$ (e.g., Sm, Fig. 7c), the disseminated sulfide-bearing samples (o) and the breccia-matrix sulfides with ultramafic fragments lie along a trend between the estimated composition of the liquid and the composition of the olivine. The breccia samples with sedimentary rock fragments plot toward the field of the sedimentary rocks. (Note that to avoid the effects of variable sulfide content in the rocks, the data shown in the figures have been recalculated to $100 \%$ silicate and oxides). The $\mathrm{Cr}$ versus $\mathrm{Sm}$ plot shows a similar trend (Fig. 7d). The average olivine cumulate with disseminate sulfides seems to be a mixture of approximately $30 \%$ ferropicritic liquid, $50 \%$ cumulate olivine, $0.075 \%$ chromite and $20 \%$ sulfide liquid (Tables 1, 2).

IABLE 2. CHALCOPHLE ELEHENT CONCENTRMT IONS DN ROCKS AND STLFIDE SEPARATES, PLCHENCA, RUSSIA (continued)

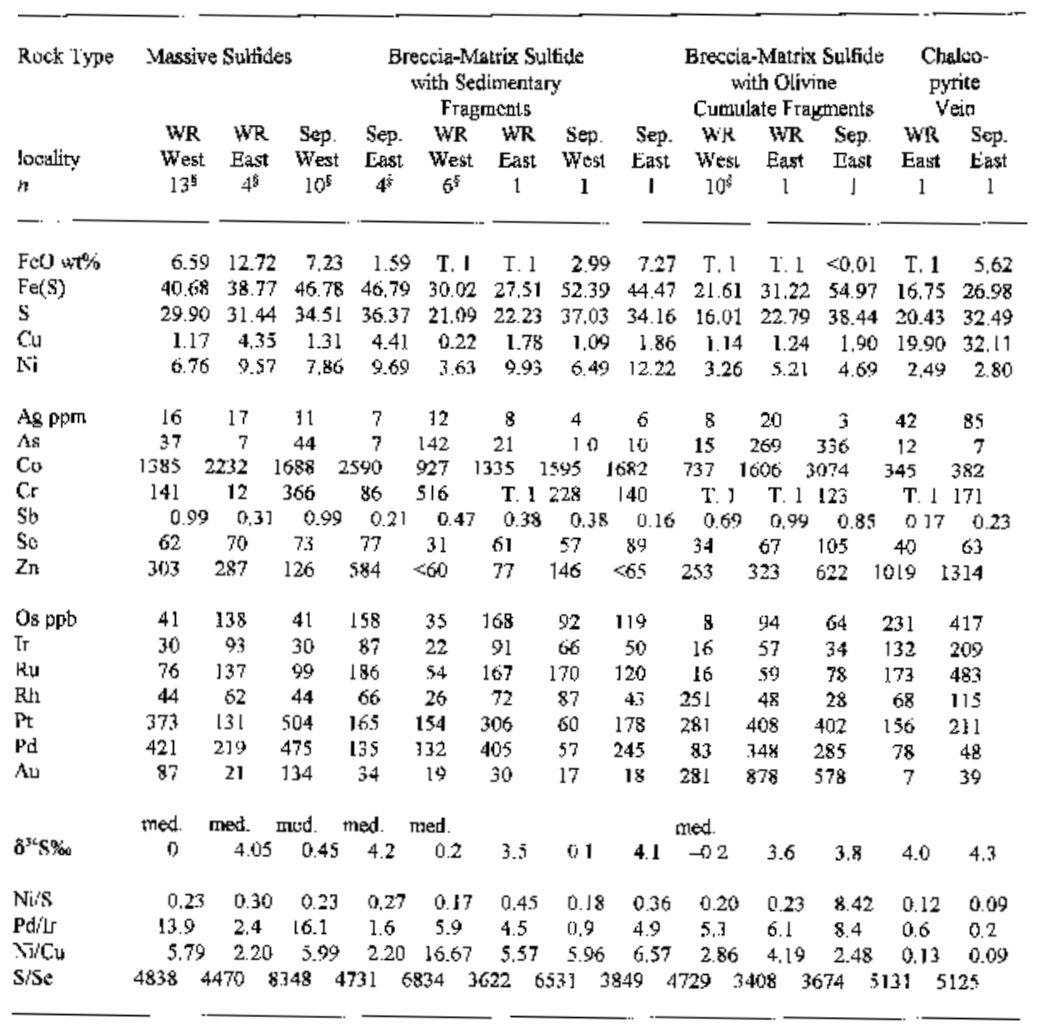

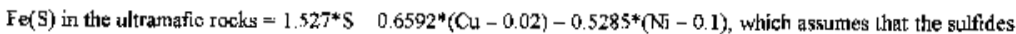

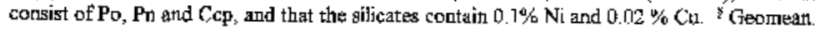

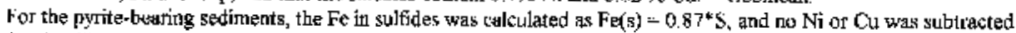
for the silicate component, Con, : concretion, med.: median, WR: whole rock, Sep.: separare. T. J: Tuble 1 

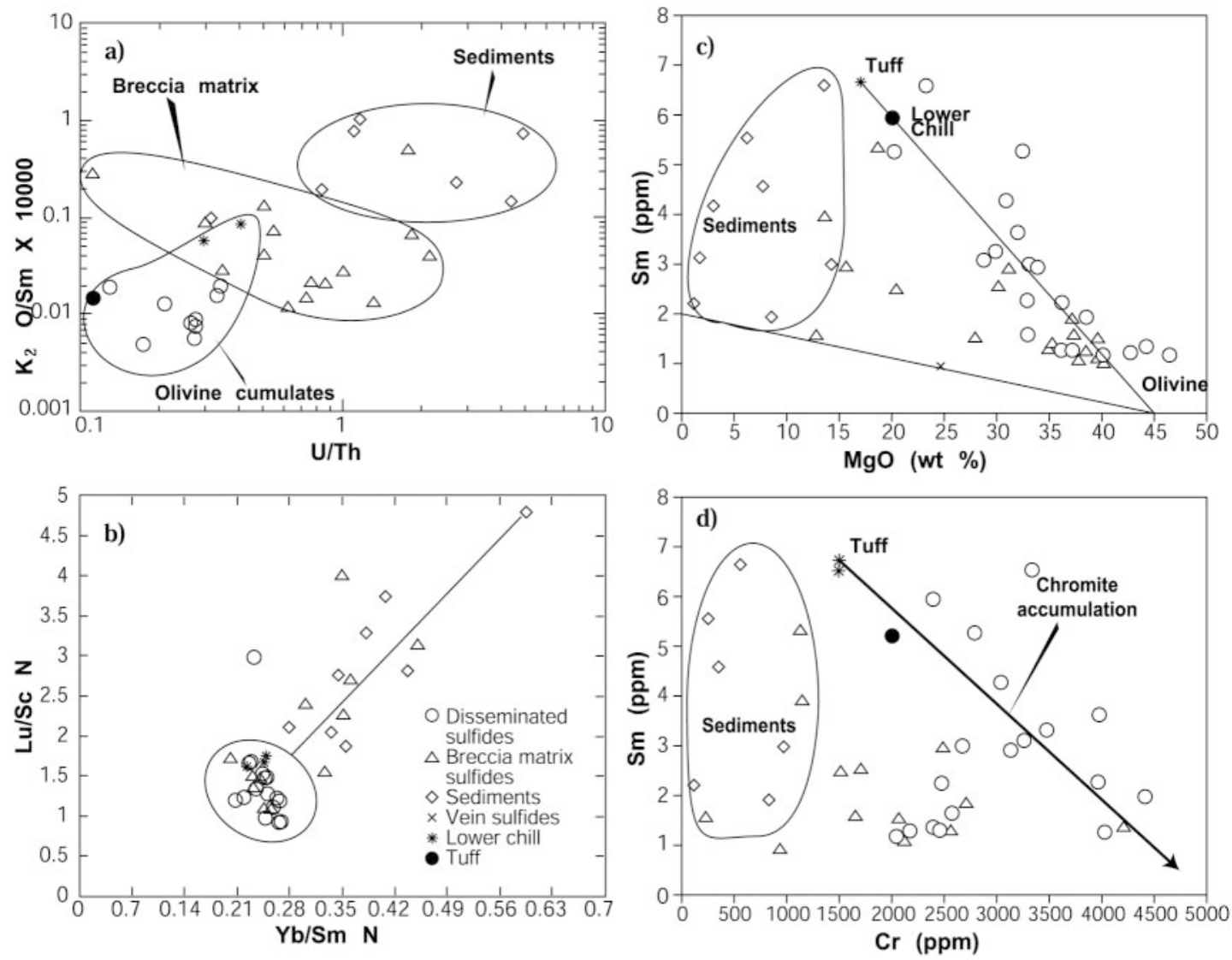

FIG. 7. a. Plot of $\mathrm{U} / \mathrm{Th}$ versus $\mathrm{K}_{2} \mathrm{O} / \mathrm{Sm}$; note that the breccia-matrix sulfides plot between the olivine cumulates with disseminated sulfides and the sedimentary rocks. b. Plot of $\mathrm{Yb} / \mathrm{Sm}_{\mathrm{N}}$ versus $\mathrm{Lu} / \mathrm{Sc}_{\mathrm{N}}$; note that the olivine cumulates and tuffs plot in a tight cluster, whereas the samples of breccia-matrix sulfide plot along a mixing line with sedimentary rocks. c. Plot of $\mathrm{MgO}$ versus $\mathrm{Sm}$; note that the olivine cumulates with disseminated sulfides plot along the olivine-control line, whereas the brecciamatrix sulfides plot toward the sediments. d. Plot of Cr versus Sm concentrations.

\section{Chalcophile elements}

In considering the chalcophile elements, only the composition of tuffs can be used as an estimate of the initial liquid composition because the lower chilled margin contains $7 \%$ sulfides, so the chalcophile element contents of the chilled margin do not represent values typical of the melt. Compared with picrites from around the world, the Pechenga ferropicrite tuff is depleted in $P G E$, with only $0.1 \mathrm{ppb}$ Ir and $2 \mathrm{ppb}$ Pd. For example, in the Karaskjok belt, the picrites contain approximately $1 \mathrm{ppb}$ Ir and $10 \mathrm{ppb}$ Pd (Barnes \& Often 1990). The Cape Smith picrites contain $0.4 \mathrm{ppb}$ Ir and $10 \mathrm{ppb} \mathrm{Pd}$ (Barnes \& Picard, unpubl. data). Ocean-island basalts with $10 \% \mathrm{MgO}$ also contain more PGE, e.g., 0.2-0.5 ppb Ir and 3-16 ppb Pd (Crocket 2000, Greenough \& Fryer 1991, Rehkamper et al. 1999). This point may be illustrated on the $\mathrm{Cu} / \mathrm{Ir}$ versus $\mathrm{Ni} / \mathrm{Pd}$ plot (Fig. 8), in which the tuff $(*)$ falls well above the field of high-Mg basalts and is depleted in $P G E$ relative to $\mathrm{Cu}$ and $\mathrm{Ni}$.

On a mantle-normalized chalcophile element plot, the tuffs show a similar abundance of $\mathrm{Zn}, \mathrm{Co}, \mathrm{Ni}$ and $\mathrm{Cu}$, but are strongly enriched in $\mathrm{As}, \mathrm{Sb}$ and very depleted in $P G E$ relative to the Cape Smith picrites (Fig. 9a). The degree of fractionation of the $P G E$ as measured by the $\mathrm{Pd} / \mathrm{Ir}$ values is similar, 30 versus 20 , but the absolute concentrations of the $P G E$ are an order of magnitude lower than in the Cape Smith picrites. Brugmann et al. (2000) showed results for a larger number of flows and also found that the Pechenga ferropicrites have low concentrations of PGE. Because the partition coefficients of $P G E$ into sulfides are much higher than those of $\mathrm{Ni}$ and $\mathrm{Cu}$, segregation of sulfides from the magma, possibly as it rose to surface, or their 


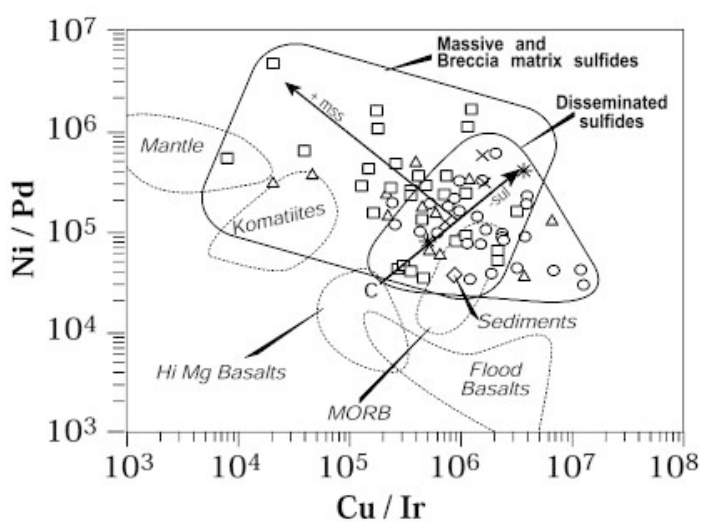

FIG. 8. Plots of Ni/Pd versus $\mathrm{Cu} / \mathrm{Ir}$ (fields from Barnes et al. 1993). Symbols: *: tuff, o: disseminated sulfides, squares: massive sulfides, triangles: breccia-matrix sulfides, diamonds: sedimentary material, $\times$ : vein sulfides, $C$ : Cape Smith spinifex. Note that most of the samples lie above the field of primitive mantle-derived partial melts, possibly owing to sulfide segregation.

retention in the mantle during partial melting, depletes the magma in $P G E$ far more than in $\mathrm{Ni}$ and $\mathrm{Cu}$. We suggest that the Pechenga magma was depleted by sulfide segregation as the magma rose to the surface and prior to the formation of the ore sulfides for the following reasons. a) The Karaskjok komatiites in Norway are not PGE-depleted (Barnes \& Often 1990); since they have similar trace-element characteristics to the Pechenga picrites and were possibly produced in a similar manner, depletion in the $P G E$ would not seem to be a characteristic of the source. b) The few modern OIB suites known with $>10 \% \mathrm{MgO}$ that have been analyzed for $P G E$ are not $P G E$-depleted (Crocket 2000, Greenough \& Fryer 1991, Rehkamper et al. 1999). Thus if the Pechenga picrites were formed in the same manner, they should not be $P G E$-depleted either. The composition of the Pechenga tuff can be modeled by removing approximately $0.01 \%$ sulfides from the composition of the Cape Smith spinifex rocks. The dashed line on Figure 8 between the composition of the Cape Smith spinifex sample (C) and the tuff (*) shows the evolution of the liquid composition as sulfides are removed.

The olivine cumulates containing disseminated sulfides from the western and eastern deposits contain similar amounts of most chalcophile elements, e.g., $1.5 \%$ $\mathrm{Ni}$ versus $2 \%$, and $0.6 \% \mathrm{Cu}$ in both sectors (Table 2 ). The interelement ratios, such as $\mathrm{Ni} / \mathrm{Cu}, \mathrm{Pd} / \mathrm{Ir}$ and $\mathrm{S} / \mathrm{Se}$, also seem similar. Thus there seems to be no significant difference in composition of the sulfides between the eastern and western deposits.

Assuming that the disseminated sulfides segregated from a ferropicritic magma similar in composition to the tuffs, it is possible to model the composition of the olivine cumulates with disseminated sulfides. Figure 10 shows a plot of $\mathrm{Cu} / \mathrm{Pd}$ versus $\mathrm{Pd}$ for the tuffs and the disseminated sulfides. The rocks containing disseminated sulfides can be modeled as a mixture of ferropicrite containing approximately $20 \%$ sulfides, which formed at $R$ factors (proportion of silicate magma to sulfide liquid: Campbell \& Naldrett 1979) between 100 and 2500. Most of the samples suggest a narrower range in $R$ (250 to 1000). This range of $R$ factors is similar to those calculated for the Cape Smith suite (Barnes et al. 1992).

It is customary to recalculate concentrations of chalcophile elements to $100 \%$ sulfides in order to eliminate the dilution effects of the silicate and oxide phases. This approach is only justified if the chalcophile elements are mainly in the sulfide phase. This hypothesis can be tested in the case of the Pechenga sulfides, because in many cases compositions of both whole-rock and sulfide separates are available for the same sample. The mantle-normalized distribution of chalcophile elements in plots of the separates and the recalculated sulfides are normally very close. Examples of this agreement are shown for disseminated sulfides, brecciamatrix sulfides and vein sulfides (Fig. 11). In all cases, there is a close match for all the elements with the exception of As in the disseminated ore. Given the close similarity between the chalcophile element patterns for separates and whole rocks, we consider it justified to recalculate them to $100 \%$ sulfides. The geomeans of the recalculated values are shown in Table 3.

Mantle-normalized chalcophile-element patterns for the disseminated sulfides show an overall increase from 10 times mantle at $\mathrm{Zn}$ to 30 times mantle at Ni (Fig. 9a). Like the picrite, the disseminated sulfides are depleted in $P G E$ relative to $\mathrm{Ni}, \mathrm{Cu}$ and $\mathrm{Ag}$. The patterns fall from 30 at $\mathrm{Ni}$ to 3 at $\mathrm{Ir}$. From $\mathrm{Ru}$ to $\mathrm{Cu}$, there is an overall increase to 2000, then the pattern flattens between $\mathrm{Cu}$ and $\mathrm{Se}$. Arsenic and $\mathrm{Sb}$ values are extremely variable, but overall they decrease to around 100 times mantle. Most patterns show a negative Au anomaly.

The metal patterns of the Pechenga disseminated sulfides are subparallel to the presumed liquid (the tuff) (Fig. 9a), suggesting that the sulfides could be modeled by sulfide segregation from a liquid similar to the tuff in composition. If we assume that the composition of the silicate liquid was close to that of the tuff, the composition of average disseminated sulfide can be modeled using an $R$ factor of $\sim 250$ (Table 3).

The average of the disseminated sulfides can be compared to disseminated sulfides from Cape Smith, Talnakh, Muskox and Dunka Road at Duluth (Fig. 12). For Ni and $\mathrm{Co}$, the metal contents are similar for all of the deposits, except for Dunka Road, which contains very low $\mathrm{Ni}$. Between $\mathrm{Os}$ and $\mathrm{Au}$, Pechenga closely follows the Dunka Road disseminated sulfides, mimicking its depleted nature. The Dunka Road sulfides have experienced considerable contamination from the black shales of the Virgina Formation, and this can be seen in 

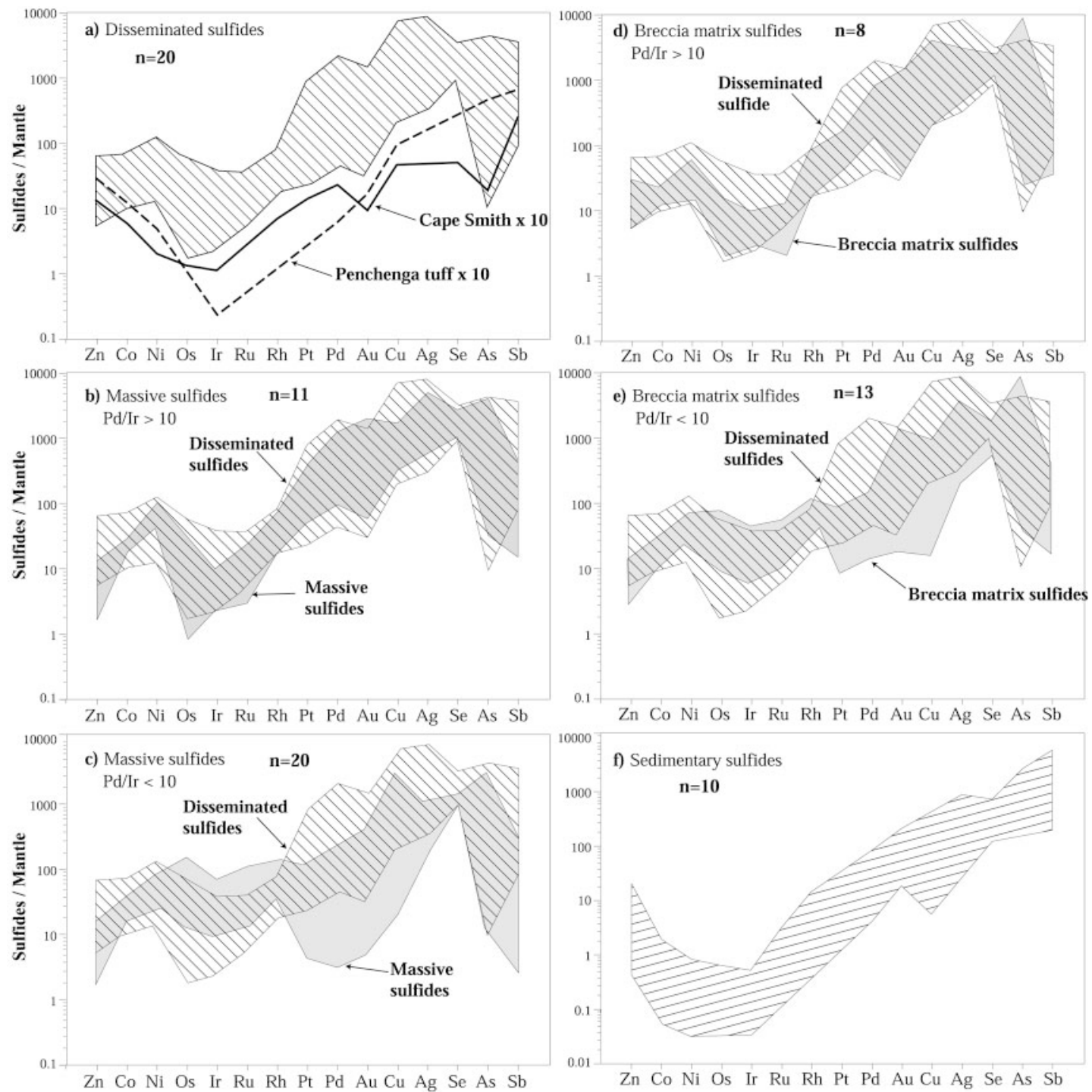

FIG. 9. Plots of mantle-normalized concentrations of chalcophile elements (normalization values from McDonough \& Sun 1995). a. Pechenga tuff with Cape Smith spinifex for comparison, and field of disseminated sulfides at Pechenga; note the general depletion of $P G E$ relative to other elements. b. Massive sulfides with $\mathrm{Pd} / \mathrm{Ir}>10$; note the similarity with disseminated sulfides. c. Massive sulfides with $\mathrm{Pd} / \mathrm{Ir}<10$; note the enrichment in $\mathrm{Os}$, Ir, $\mathrm{Ru}$ and $\mathrm{Rh}$, and the depletion in $\mathrm{Pt}, \mathrm{Pd}, \mathrm{Au}, \mathrm{Ag}$ and $\mathrm{Cu}$ relative to disseminated sulfides. d. Breccia-matrix sulfides with $\mathrm{Pd} / \mathrm{Ir}>10$; note the similarity with disseminated sulfides, except that some breccia-matrix sulfides are enriched in As. e. Breccia-matrix sulfide with $\mathrm{Pd} / \mathrm{Ir}<10$; note the similarity with massive sulfides with $\mathrm{Pd} / \mathrm{Ir}<10$. f. Black schists.

the enrichment of As and $\mathrm{Sb}$ in these samples. Interestingly, the Pechenga, Cape Smith and Muskox sulfides also are rich in $\mathrm{As}$ and $\mathrm{Sb}$, whereas the Talnakh sulfides are poor in these elements. Sulfide-bearing clastic sedimentary rocks are present at Pechenga, Cape Smith and Muskox, and these could have contributed the As and
Sb. In contrast, the sedimentary rocks at Talnakh are evaporites, which contain very little As or Sb.

On the Ni/Pd versus $\mathrm{Cu} / \mathrm{Ir}$ plot (Fig. 8), the rocks hosting disseminated sulfides (o) plot along the sulfideremoval curve drawn between the Cape Smith (C) and Pechenga picrites $(*)$. These samples contain sulfides 


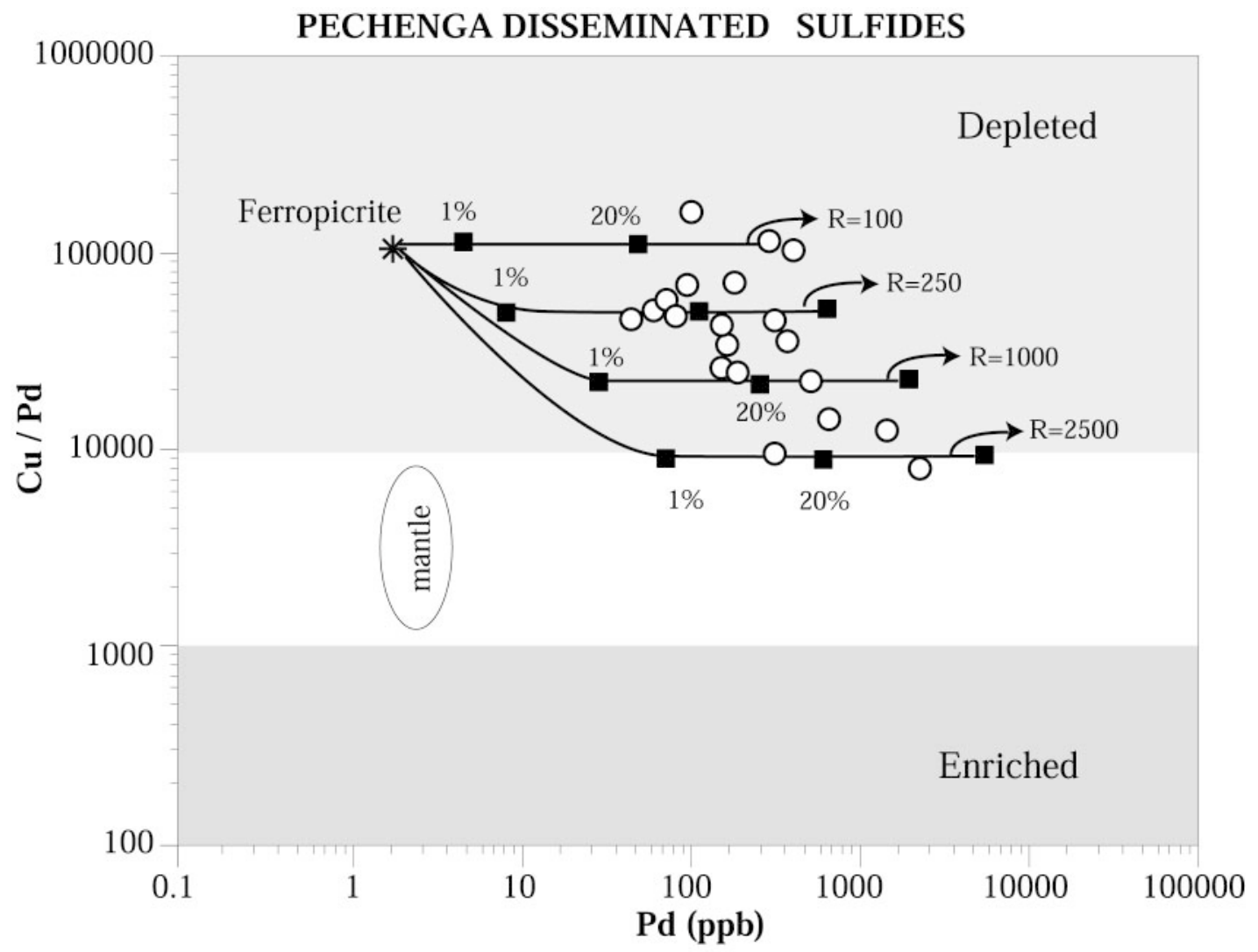

FIG. 10. $\mathrm{Cu} / \mathrm{Pd}$ versus $\mathrm{Pd}$ concentration for the disseminated sulfides. All of the samples have $\mathrm{Cu} / \mathrm{Pd}$ values in excess of mantle values, indicating that they are depleted in $\mathrm{Pd}$ relative to $\mathrm{Cu}$, possibly owing to sulfide segregation at depth. The samples lie along tie-lines between the ferropicrite and sulfides that could have formed in equilbrium with the ferropicrite at $R$ factors of 100 to 2500 . The position of the samples along the tie-lines indicates that they contain around $20 \%$ sulfides. More details on how to use this type diagram can be found in Barnes et al. (1993).

in equilibrium with a ferropicritic melt depleted in $P G E$ owing to sulfide removal. However, some of the disseminated sulfide samples plot below this curve, with high $\mathrm{Cu} / \mathrm{Ir}$ values. There are two possible reasons for this: a) during metamorphism and deformation, $\mathrm{Cu}$ could have been added to the samples, or b) $\mathrm{Cu}$ was preferentially added to the magma from which these samples formed (i.e., contamination of the magma). The samples that have the high $\mathrm{Cu} / \mathrm{Ir}$ values do not seem to be more altered than those with normal values; thus the addition of $\mathrm{Cu}$ during metamorphism does not seem to be the cause. Anoxic black shales are known to concentrate $\mathrm{Cu}$ over Ni (Calvert 1976), and the Pechenga black schists and sulfide separates are enriched in $\mathrm{Cu}$ over $\mathrm{Ni}$ (Table 2). Thus the $\mathrm{Cu}$ may have been derived from the shale.

Massive sulfides and the separates from the western and eastern deposits contain similar amounts of $\mathrm{Ni}, 6$ and $8 \%$, respectively (Table 2). But the eastern deposits have higher Os, Ir, Ru and Rh values, and lower concentrations of almost all other elements. Similar features are observed in many massive ore deposits (Barnes et al. 1997, and references therein) and are possibly explained if some of the massive sulfide is actually a sulfide cumulate that contains monosulfide solid-solution (Mss).

On the $\mathrm{Cu} / \mathrm{Ir}$ versus $\mathrm{Ni} / \mathrm{Pd}$ plot, some massive sulfides (Fig. 8, squares) plot along the curve for sulfide removal and presumably represent compositions of frozen sulfide liquid in equilibrium with the ferropicritic magma. But many massive sulfides have much higher $\mathrm{Ni} / \mathrm{Pd}$ and lower $\mathrm{Cu} / \mathrm{Ir}$ values, resulting in extension of the massive sulfide field into the upper right portion of the diagram along the "accumulation of Mss" vector. In order to investigate this idea further, the massive sulfides have been divided into two groups, those that have 

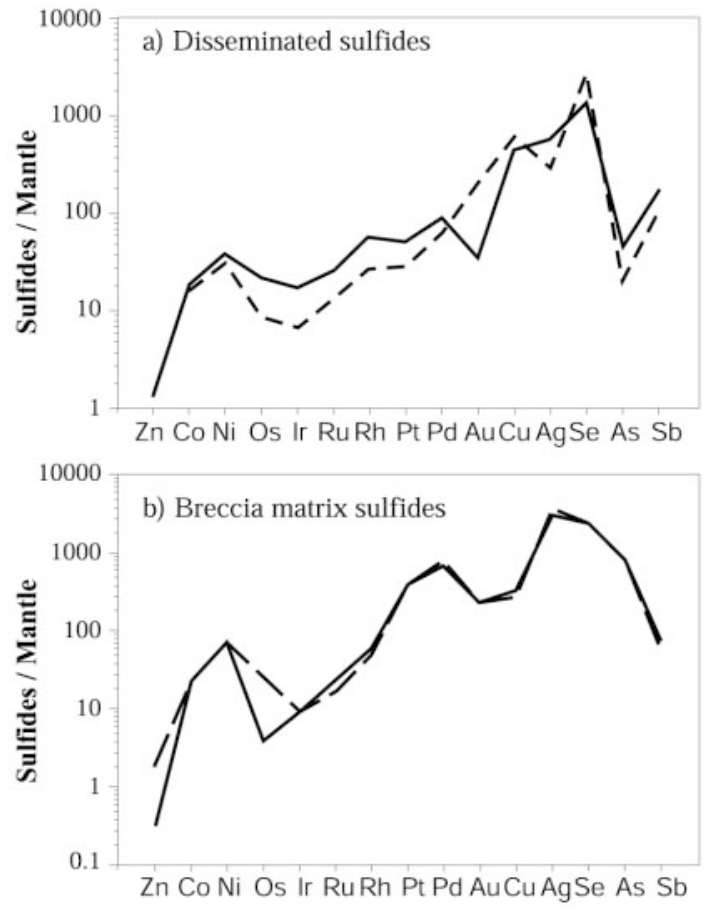
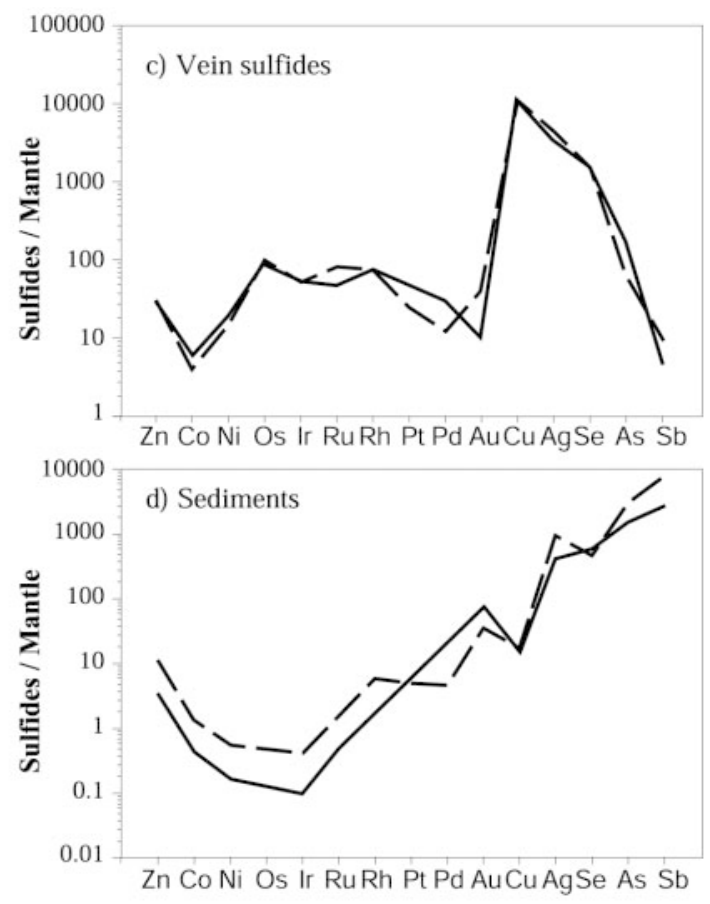

FIG. 11. Separates (solid line) and recalculated composition (dashed line) of sulfides. Note that the shape of the patterns is similar, indicating that most of the chalcophile elements are present in the sulfides.

$\mathrm{Pd} / \mathrm{Ir}$ values similar to the disseminated ores $(\mathrm{Pd} / \mathrm{Ir}>10)$ and that presumably represent close-to-liquid compositions, and those with $\mathrm{Pd} / \mathrm{Ir}<10$, which presumably represent $M s s$ cumulate (Table 3).

The accumulation of $M s s$ at other deposits, e.g., Duluth (Thériault \& Barnes 1998) tends to enrich the rocks in $\mathrm{Os}, \mathrm{Ir}, \mathrm{Ru}$ and $\mathrm{Rh}$ and, to a lesser extent, $\mathrm{Ni}$, whereas most other elements are excluded. The same effect can be seen at Pechenga on the mantle-normalized chalcophile-element patterns (Fig. 9b). The massive ores with $\mathrm{Pd} / \mathrm{Ir}$ values greater than 10 resemble the disseminated ores both in shape and level. The massive sulfide with $\mathrm{Pd} / \mathrm{Ir}$ greater than 10 appears to have formed in much the same way as the disseminated sulfide. The massive sulfides with $\mathrm{Pd} / \mathrm{Ir}$ less than 10 have very flat chalcophile-element patterns from Co to $\mathrm{Au}$ (Fig. 9c). The $\mathrm{Zn}, \mathrm{Ni}$ and Co concentrations are similar to the disseminated ore, but they are enriched in $\mathrm{Os}, \mathrm{Ir}, \mathrm{Ru}$ and $\mathrm{Rh}$, and depleted in $\mathrm{Pt}, \mathrm{Pd}, \mathrm{Au}, \mathrm{Ag}, \mathrm{Sb}$ and $\mathrm{As}$.

The composition of the massive sulfides with $\mathrm{Pd} / \mathrm{Ir}$ less than 10 can be numerically modeled using partition coefficients similar to those estimated by Thériault \& Barnes (1998) by assuming that it is an Mss cumulate with approximately $30 \%$ trapped liquid (Table 3 ).

In terms of whole-rock concentrations, the brecciamatrix sulfides contain lower concentrations of most chalcophile elements than massive sulfides from which they are considered to have formed. For example, Ni concentrations in rocks containing breccia-matrix sulfide is normally $3-5 \%$ compared with 6.5 to $8.5 \%$ in the massive-sulfide-bearing rocks (Table 2). An exception to this is As, which tends to be present in higher concentrations in the breccia-matrix-sulfide-bearing rocks. The lower concentration of chalcophile elements in the breccia-matrix sulfides could in part be due to the dilution effect of rock fragments that contain very sparse amounts of the chalcophile elements. However, even if the elements are recalculated to $100 \%$ sulfides, the breccia-matrix sulfide appears to have lower chalcophileelement concentrations than the massive sulfides, except for As, $\mathrm{Sb}$ and $\mathrm{Zn}$ (Table 3). This observation may reflect the presence of fragments of sedimentary rocks in many of the breccia-matrix sulfides. The sedimentary rocks contain 3 to $40 \%$ pyrite. The sedimentary sulfide would contribute $\mathrm{S}, \mathrm{As}, \mathrm{Sb}$ and $\mathrm{Zn}$ to the rock, but add very little of the other chalcophile elements. Thus the concentration of most chalcophile elements would appear to decrease, whereas that of $\mathrm{As}, \mathrm{Sb}$ and $\mathrm{Zn}$ should increase. The composition of the breccia-matrix sulfides can be approximated if they are considered to be a mixture of approximately $80 \%$ massive sulfide and $20 \%$ sedimentary sulfide (Table 3 ). 
TABLE 3. ESTIMATED COMPOSTTION OF THE SULFDES AND MODELS FOR THEIR FORMATION, PECHENGA SUITE

\begin{tabular}{|c|c|c|c|c|c|c|c|c|c|c|c|c|c|c|c|c|c|c|}
\hline \multirow{2}{*}{ Dissemitnated } & \multirow{2}{*}{$\begin{array}{c}n \\
20\end{array}$} & \multirow{2}{*}{$\begin{aligned} \mathrm{Fe} \% \\
-48.26\end{aligned}$} & \multirow{2}{*}{$\frac{S}{37.07}$} & \multirow{2}{*}{$\frac{\mathrm{Cu}}{3.59}$} & \multicolumn{3}{|c|}{$\mathrm{Nj} \mathrm{Ag} \mathrm{ppm} \mathrm{As}$} & \multirow{2}{*}{$\underbrace{C o}_{2540}$} & \multirow{2}{*}{$\begin{array}{l}5 b \\
4.0\end{array}$} & \multirow{2}{*}{$\begin{array}{c}\text { Se } \\
75\end{array}$} & \multicolumn{2}{|c|}{$\mathrm{Zn} \mathrm{Osppb}$} & \multirow{2}{*}{$\frac{\text { Ir }}{26}$} & \multirow{2}{*}{ Ru } & \multirow{2}{*}{$\begin{array}{r}\mathbf{R h} \\
36\end{array}$} & \multirow{2}{*}{$\begin{array}{c}\text { Pt } \\
810\end{array}$} & \multirow{2}{*}{$\frac{\mathrm{Pd}}{867}$} & \\
\hline & & & & & 8.58 & 27 & 31 & & & & 573 & 26 & & & & & & \\
\hline Massive & 31 & 49.76 & 37.35 & 1.94 & 8.89 & 12 & 28 & 2024 & 0.6 & 80 & 179 & 64 & 45 & 112 & 55 & 359 & 386 & \\
\hline Breccta Matrix & 21 & 51.75 & 37.76 & 1,35 & 7.41 & 32 & 55 & 1820 & 09 & 74 & 261 & 44 & 37 & 68 & 48 & 398 & 379 & 1 \\
\hline Vein & 2 & 28,59 & 34.43 & 34.02 & 2.90 & 90 & 7 & 405 & 0.2 & 67 & 1392 & $442=$ & 221 & 511 & 122 & 223 & 51 & \\
\hline Sedimentary & 10 & 44.75 & 53,42 & 0.13 & 0.08 & 2 & 138 & 92 & 11.3 & 20 & $28]$ & $\leqslant 50$ & 0.47 & $<5$ & 2 & $<10$ & 10 & \\
\hline Massive Pd/lis $<10$ & 20 & 50.26 & 37.48 & 1.73 & 8.26 & 7 & 15 & 2097 & 0.3 & 71 & 187 & 118 & 67 & 173 & 65 & 216 & 193 & \\
\hline Massive Pd/Tr $>10$ & 11 & 48.86 & 37.12 & 2.41 & 10.15 & 29 & 76 & 1905 & 1.3 & 100 & 165 & 22 & 23 & 56 & 41 & 865 & 1279 & \\
\hline BIexcia PdTr $=10$ & 13 & 52.69 & 37.91 & 0,97 & 7.29 & 8 & 63 & 1776 & 0.5 & 73 & 190 & 74 & 50 & 113 & 56 & 287 & 200 & \\
\hline \multirow[t]{2}{*}{ Breccia PdTr $=10$} & 8 & 50.26 & 37.53 & 2.34 & 7.61 & 25 & 43 & 1894 & 2.0 & 76 & 438 & 19 & 23 & 33 & 39 & 623 & 913 & \\
\hline & & $\mathrm{Cu} \%$ & Ni $\%$ & $\mathrm{ppm}$ & As & $\mathrm{Co}$ & & $s$ & & Zn & Os ppb & lr & & Ru & $R \hbar$ & $\mathrm{Pt}$ & $\mathrm{Pd}$ & \\
\hline \multicolumn{19}{|c|}{ Model 1 : Disseminated sulfide fornted by segregation from the ferropicrite tuff } \\
\hline $\mathrm{R}=250$ & & 3.35 & 9.05 & 20 & 35 & 2412 & & 3.9 & 84 & 512 & 40 & 40 & & 60 & 40 & 799 & 799 & \\
\hline $\mathrm{C}_{\mathrm{n}}$ & & 0.02 & 0.09 & 0.12 & 9.00 & 60 & & 1.0 & 0.5 & 130 & 0.20 & 0.20 & & 30 & 0.20 & 4 & 4 & \\
\hline$D$ & & 1000 & 200 & 1000 & 4 & 50 & & 4.0 & 000 & 4 & 30000 & 30000 & 3000 & 0003 & 0000 & 30000 & 30000 & \\
\hline
\end{tabular}

Model 2: Massive sulfide Pd/1 410 as $M$ ss cumulate wilh $30 \%$ trapped liquid after $70 \%$ fractionation

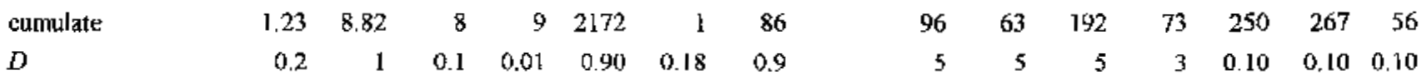

Model 3: Breccia-matrix sulfide as a mixture of $80 \%$ massive sulfides and $20 \%$ sedimentary sulfide

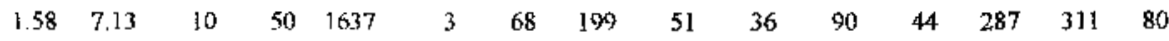

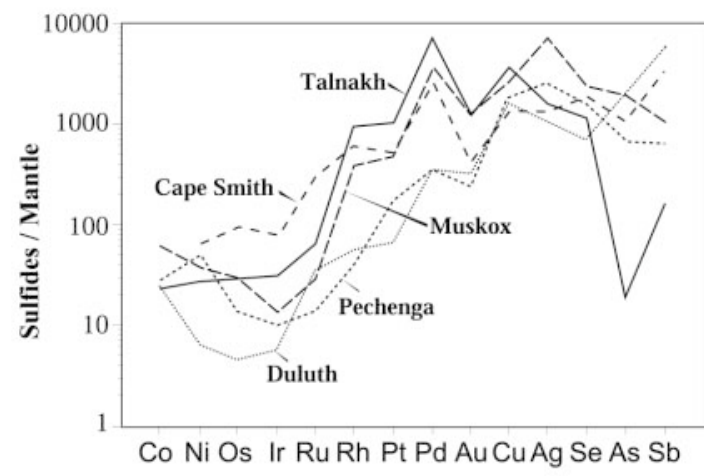

FIG. 12. Comparison of the composition of the disseminated sulfides with that of disseminated sulfides from Cape Smith, Duluth, Muskox and Noril'sk (Talnakh).
On the plots of ratios (Fig. 8), the breccia-matrix sulfides plot with the massive ore, and thus the $\mathrm{Cu} / \mathrm{Ir}$ and $\mathrm{Ni} / \mathrm{Pd}$ seem undisturbed by the process of brecciation. The wide range in ratios suggests that the brecciamatrix sulfides, like the massive sulfides, have experienced $M s s$ fractionation. For the plots of the chalcophile elements, the sulfides were divided into those with $\mathrm{Pd} / \mathrm{Ir}$ greater than 10 and those with $\mathrm{Pd} / \mathrm{Ir}$ less than 10 . The samples with $\mathrm{Pd} / \mathrm{Ir}$ greater than 10 have plots of chalcophile element concentrations (Fig. 9d) that resemble those of the disseminated sulfides, although some are richer in As, presumably owing to the presence of the sedimentary component. Just as in the case of the massive sulfides, the samples with brecciamatrix sulfide with $\mathrm{Pd} / \mathrm{Ir}$ values less than 10 (Fig. 9e) are richer in $\mathrm{Os}, \mathrm{Ir}, \mathrm{Ru}$ and $\mathrm{Rh}$, and depleted in most other elements, probably owing to the presence of Mss as a cumulate phase. 
A number of samples seem to contain stringers of sulfides in the country rock, but these have compositions close to those of the massive sulfides and are included with them. Only one sample (\#5) was taken from a chalcopyrite-rich vein. Both the whole rock and the sulfide separate were analyzed. Chalcopyrite is the main sulfide present and, consequently, the sulfide is extremely rich in $\mathrm{Cu}$ (Tables 2, 3). It is also rich in $\mathrm{Ag}$. Most $\mathrm{Cu}$-rich veins associated with magmatic ore deposits are depleted in $\mathrm{Os}, \mathrm{Ir}, \mathrm{Ru}$ and $\mathrm{Rh}$, and enriched in most other chalcophile elements. The vein material normally is considered to represent a fractionated sulfide liquid that was injected into the country rock. However, in this case, the vein sulfides have a very unusual composition. In addition to being enriched in $\mathrm{Cu}$ and $\mathrm{Ag}$, they are enriched in Os, Ir, Ru and $\mathrm{Rh}$, and depleted in most other chalcophile elements (Tables 2, 3, Fig. 11d). The reasons for this are not understood at this time.

\section{Compositional variations along traverses and between the eastern and western deposits}

Some samples were taken along ten short traverses from the country rock into the intrusion to determine whether there is any change in composition of the sulfides, as is observed at Dunka Road and Muskox (Thériault \& Barnes 1998, Barnes \& Thériault 1998, Thériault et al. 2000). There, sulfides closest to the country rock show the greatest degree of contamination. Moreover, Walker et al. (1997) attributed a variation in the Re/Os isotopes at Pilgujärvi to an increase in the degree of contamination close to the margins of the flow. We also wished to compare the composition of sulfides from the presumed flows erupted onto unconsolidated sediments (western deposits) with those emplaced into consolidated sediments (eastern deposits). No clear pattern emerged. In part, this is because most Pechenga traverses contain at least three different types of sulfides (disseminated, massive and brecciamatrix sulfide), unlike the Muskox and Dunka Road traverses, which contain predominantly disseminated sulfides. The variations in composition among the different types of sulfides obscure any variation that could be attributed to the effects of variable degrees of contamination or to differences in the composition of consolidated and unconsolidated sediments.

As will be outlined in the model section, the contamination process did not necessarily take place in situ. It is possible that $S$ and other volatile elements were transferred to the magma by devolatilization of the sedimentary rocks to bring about sulfide saturation, and that, as in the case of komatiite flows, the magma could have transported the sulfide droplets some distance before the sulfides settled out. In this case, a strong correlation between distance from the margins of the flow, or intrusion, and the degree of contamination might not be evident.

\section{Sulfur isotopes}

The $\delta^{34} \mathrm{~S}$ values of disseminated sulfides, massive sulfides and breccia-matrix sulfides from the western deposits are all close to zero (Table 2, Fig. 13), and there is no difference in $\delta^{34} \mathrm{~S}$ among types of sulfide ores. Similarly, there is no difference in $\delta^{34} \mathrm{~S}$ among disseminated, massive and breccia-matrix sulfides from the eastern deposits. But the sulfides from the eastern deposits have higher $\delta^{34} S$ than those from the western deposits (Table 2, Fig. 13). Our data confirm previously reached conclusions (Grinenko et al. 1967, Abzalov \& Both 1997) that the eastern group of deposits can be clearly distinguished from the western by their higher $\delta^{34} \mathrm{~S}$ values of ore sulfides. Further, the sulfur isotope values of ores and their host ultramafic bodies are comparable, as was also observed by Grinenko \& Smol'kin (1991).

The sulfur isotope values obtained in this study for the pyrite from sediments confirm the results of Melezhik et al. (1998). The layers and concretions of syngenetic and early diagenetic pyrite have low $\delta^{34} \mathrm{~S}(-4.5$ to $+2 \%$ ), whereas those from the cataclastic and coarse-grained pyrite are high ( +8 to $+20.9 \%$ ) .

\section{DisCUSSION}

The ferropicrites of the Pechenga area are not the only examples to show such strong enrichment in LILE, LREE and HFSE. It is important to note that rocks of similar age are found throughout the northern Baltic Shield, extending from the Norwegian Karasjok komatiites in the west (Barnes \& Often 1990) to the Russian Imandra-Varzuga Belt in the east. Puchtel $e t$ al. (1999) have suggested that the geology of the whole area could be explained as the result of plume activity, and that the ferropicrites have a small component of outer core material in them. Whether it is necessary to invoke the presence of outer core material could be questioned; Francis et al. (1999) argued that the Archean and Proterozoic picrites are 30\% richer in Fe than modern OIB, and that this enrichment is due to the greater amount of $\mathrm{Fe}$ in the mantle during the Archean and the Proterozoic. Using these observations and the model of Melezhik \& Sturt (1994), the tectonic setting at the time of the ferropicrite emplacement (Fig. 5) would have consisted of rifted Archean basement onto which shallow-water clastic sediments had been deposited and tholeiitic and alkali basalts were erupted (Ahmalahti, Kuetsjärvi and Kolasjoki formations). In turn, these were overlain by the black schists of the Pilgujärvi Formation. The ferropicritic magma, which by analogy with OIB would be derived from the plume stem, was emplaced into and onto the sediments.

In order to form an ore deposit, the magma had to become saturated in sulfides. A common model of promoting saturation in a sulfide fraction is to contaminate 

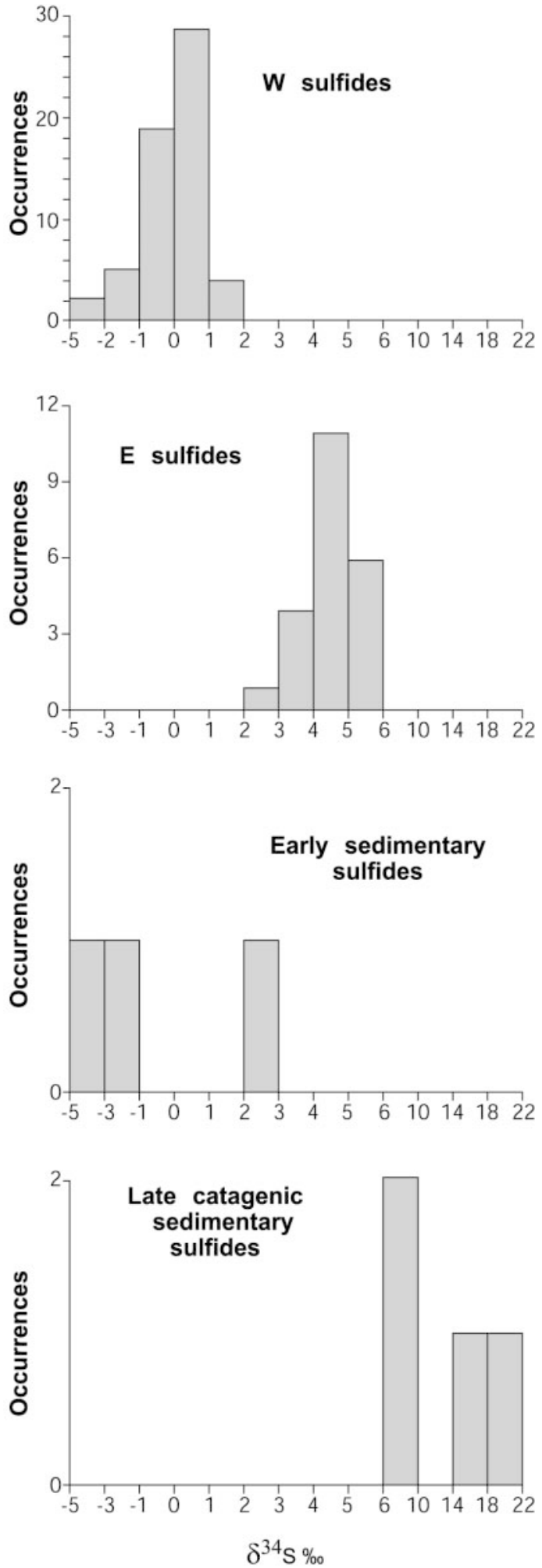

the magma with S-rich sediments (Lesher \& Campbell 1993). At Pechenga, the physical evidence for contamination is compelling. The orebodies are only found within the S-rich black schists. The bleached zones in the schists in contact with flows and intrusions are depleted in sulfides, suggesting that sulfides and carbon have been extracted from the schists. Furthermore, the $\mathrm{S}$ isotopes from the eastern bodies and the Re/Os isotopes suggest that contamination by sedimentary material was an important factor in forming these bodies. These observations must somehow be reconciled with the following observations: a) the lithophile elements of the tuff and the olivine cumulates containing disseminated sulfide do not show classic signs of contamination, and $b$ ) the $S$ isotopes of the western bodies are close to mantle values, suggesting that contamination has not occurred.

Contamination of the picrite could have occurred in three possible ways: a) the country rocks could have been completedly melted, with the melt mixed into the picritic magma (i.e., bulk assimilation), b) the country rock could have been partially melted, and only the melt mixed into the picritic magma, or c) the country rock could have been devolatilized by heat from the picritic magma, and those elements that easily enter the vapor phase could have been transferred to the picritic magma.

Bulk assimilation of the sediments into the picritic magma can be modeled by a simple mixing process; in fact, the breccia-matrix sulfide with fragments of sedimentary rock, which is the result of simple mechanical mixing, illustrates how the trace elements would be affected: U, LILE, K, HREE, $\mathrm{Al}_{2} \mathrm{O}_{3}$, As and $\mathrm{Sb}$ (Figs. 6, 7 and 9) are enriched, and the other elements are depleted. However, the lithophile elements suggest that bulk assimilation has not occurred in the case of the olivine cumulates with disseminated sulfides or the ferropicrite.

A second possibility is that the sulfide in the country rocks melted and only the sulfide was absorbed by the ferropicritic magma. The sedimentary sulfides contain more $\mathrm{S}, \mathrm{Cu}, \mathrm{Ag}, \mathrm{As}, \mathrm{Au} \mathrm{Sb}$ and $\mathrm{Se}$ than the ferropicrite, and similar concentrations of $\mathrm{Ni}, \mathrm{Co}$ and the $P G E$ (Table 3, Fig. 9). Thus, we might expect contamination of the ferropicrite by the sedimentary sulfide to raise the $S$, $\mathrm{Cu}, \mathrm{Ag}, \mathrm{As}, \mathrm{Au}, \mathrm{Sb}$ and $\mathrm{Se}$ concentrations of the ferropicrite. The ferropicritic magma can only dissolve $3000 \mathrm{ppm} \mathrm{S}$, and this limits the amount of sedimentary sulfide that could be absorbed by simple bulk mixing to $0.5 \%$, which is too small an amount to effect the concentrations of $\mathrm{As}, \mathrm{Sb}$ and $\mathrm{Cu}$ in the magma, and thus

FIG. 13. Sulfur isotope compositions for this suite. The eastern sulfides have higher $\delta^{34} S$ values than the western sulfides, and syngenetic and early diagenetic sulfides have low $\delta^{34} \mathrm{~S}$, but the late diagenetic and catagenetic sulfides have high $\delta^{34} \mathrm{~S}$. 

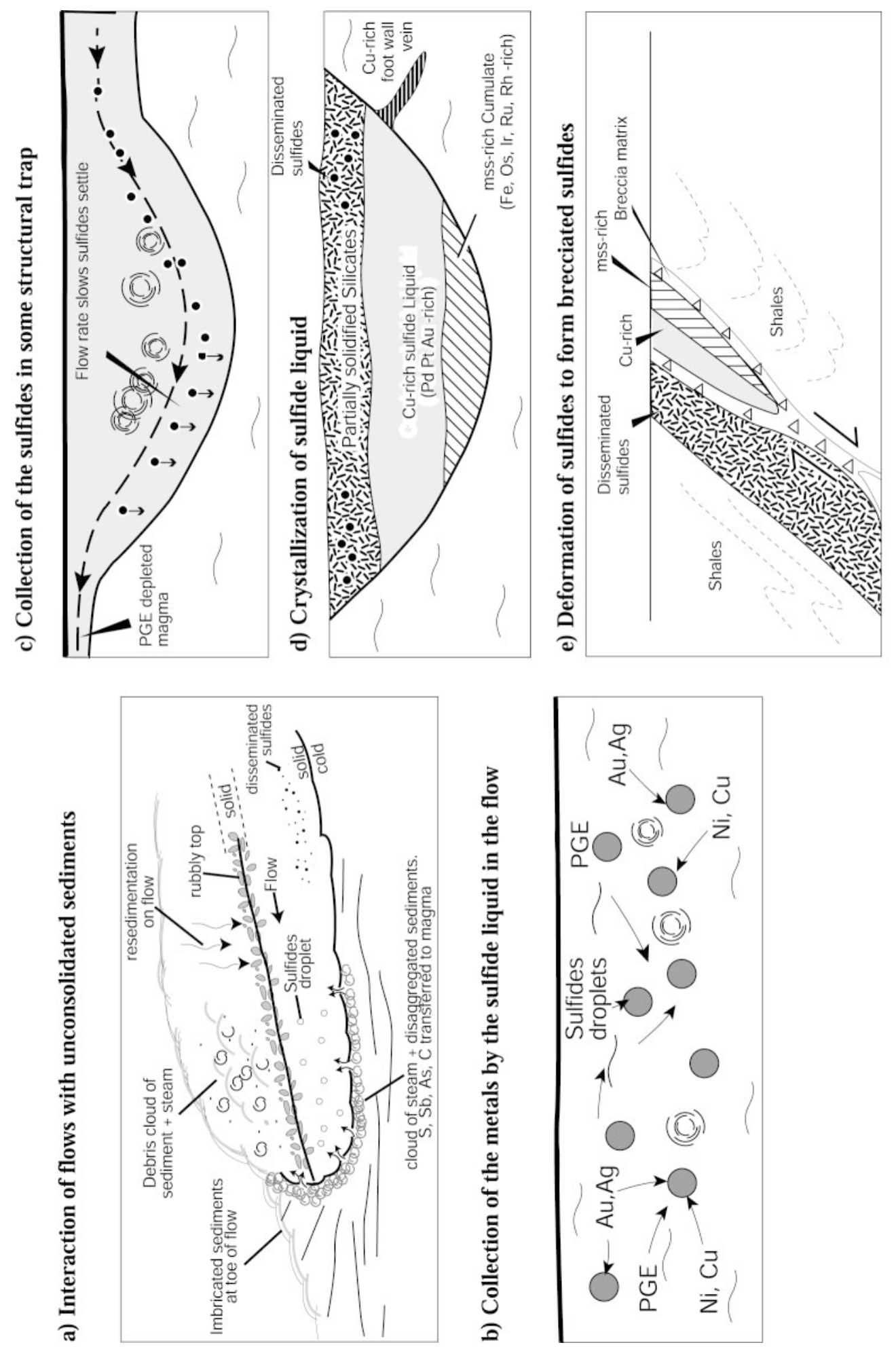

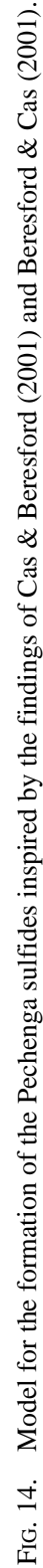


will not account for the observed enrichment in $\mathrm{As}, \mathrm{Sb}$ and $\mathrm{Cu}$. For example, in order to raise the $\mathrm{Cu} / \mathrm{Ir}$ values to $10^{8}$ as observed in some samples, the $\mathrm{Cu}$ concentrations in the magma would have to rise from the 100 to $200 \mathrm{ppm}$ found in the tuffs to $1000 \mathrm{ppm}$. The sedimentary sulfide contains $1000 \mathrm{ppm}$. Thus simple bulk mixing of the sedimentary sulfide into the picritic magma would not raise the $\mathrm{Cu}$ concentrations sufficiently.

An alternative possibility is that some metals could have been transferred to the magma by devolatilization of the sedimentary host. This type of contamination has been suggested at other deposits (Duluth: Ripley 1981, Thériault \& Barnes 1998; Vammala: Peltonen 1995). Contamination caused by devolatilization of unconsolidated or consolidated sediments containing carbonates, organic matter, sulfates and sulfides is a more complex hypothesis to evaluate. Conductive transfer of heat would generate mobile gaseous compounds. The bleached zones around some xenoliths at Pechenga could be the remains of such a process. We envisage the picrite creating a cloud of steam and disaggregated sediments as it passed over the sea floor. The gas transferred $\mathrm{S}, \mathrm{Sb}, \mathrm{As}, \mathrm{C}$ and possibly $\mathrm{Cu}$ from the sedimentary material to the magma (Fig. 14a).

The sudden increase in sulfur concentration and decrease in $f\left(\mathrm{O}_{2}\right)$ provoked sulfide saturation in the magma. Sulfide droplets (possibly represented by the globular sulfides) formed, and these collected most chalcophile elements (Fig. 14b). The ratio of silicate magma to sulfide liquid appears to have varied from 100 to 2500. Provided that the magma was flowing sufficiently rapidly, the sulfide droplets would be transported by the magma. When the magma flow-rate slowed, such as when the magma passed over an uneven surface (Fig. $14 \mathrm{c})$, the sulfide droplets could be expected to settle out of the magma. After the magma passed over the uneven topography, it would be $P G E$-depleted. If it continued to flow over the sedimentary material, it might absorb more sulfur and create new droplets of sulfide. These sulfides would be very $P G E$-depleted.

If sulfide droplets settled out of the magma along with olivine crystals, a pile of olivine with interstitial sulfide liquid would have formed, to solidify into the olivine cumulates with disseminated sulfides. In some cases, very little olivine accumulated, and a pool of sulfide liquid formed. Monosulfide solid-solution crystallized from the liquid, and an Mss cumulate formed, enriched in Os, Ir, Ru and $\mathrm{Rh}$, leaving a fractionated liquid rich in $\mathrm{Pt}, \mathrm{Pd}, \mathrm{Au}, \mathrm{Ag}, \mathrm{As}, \mathrm{Sb}, \mathrm{Se}$ and $\mathrm{Cu}$. Thus the massive sulfides developed their wide range of compositions (Fig. 14d).

During deformation, movement occurred both along the upper and lower margins of the massive sulfides, and these appear to have been mixed with fragments of both the ultramafic rocks and the sedimentary material to produce the breccia-matrix sulfide (Fig. 14e). This mechanical mixing lowered the concentration of most metals in the rocks, but raised the $\mathrm{Sb}$ and As content.
The process also raised the LILE, $\mathrm{U}, \mathrm{Al}$ and $\mathrm{V}$ contents of the rocks bearing the breccia-matrix sulfides.

\section{Conclusions}

There is a difference in composition between the disseminated sulfides and the massive and brecciamatrix sulfides in that the disseminated sulfides are poorer in $\mathrm{Os}, \mathrm{Ir}, \mathrm{Ru}$ and $\mathrm{Rh}$, and richer in $\mathrm{Pt}, \mathrm{Pd}, \mathrm{Au}$, $\mathrm{Cu}, \mathrm{Ag}, \mathrm{Se}, \mathrm{Sb}$ and As. Elements such as $\mathrm{Ni}$ and $\mathrm{Co}$ have similar concentrations in all three types of sulfides. The difference between the disseminated sulfides and the massive and breccia-matrix sulfides may be attributed to the presence of cumulus Mss in the massive and breccia-matrix sulfides, which enriched these sulfides in compatible chalcophile elements. There is a difference in composition between the massive and brecciamatrix sulfides: the latter are richer in $\mathrm{As}$ and $\mathrm{Sb}$, and are slightly poorer in most other metals. This difference may be attributed to the presence of sedimentary sulfides in the breccia-matrix sulfides. The sedimentary sulfides are poor in all metals except As and Sb. Only one sample of $\mathrm{Cu}$-rich vein material was analyzed. This sample has a very unusual composition, having been enriched in $\mathrm{Cu}, \mathrm{Ag}$ and the immobile chalcophile elements. It is not possible at this time to say whether all the vein material has these characteristics.

The samples from the western bodies and eastern bodies appear to be similar. However, there are insufficient samples of each type to study this question in depth. The possibility that there is a difference between the two areas cannot be eliminated.

The $\mathrm{S}$ isotopes suggest that sulfur was derived from the country rocks. Physical evidence suggests that this transfer was achieved by devolatilization of the partially consolidated organic-matter-rich and S-rich sediments. Arsenic and Sb may have been transferred along with sulfur into the magma. The disseminated sulfides can be modeled as having segregated from the ferropicritic magma using $R$ factors of 100 to 2500 . The noble metals are depleted relative to $\mathrm{Ni}$ and $\mathrm{Cu}$, suggesting that a small quantity of sulfides segregated from the magma on its way to the site of emplacement. The massive sulfides can be modeled as Mss cumulates. The brecciamatrix sulfides appear to consist of a mixture of the massive sulfides and the sedimentary sulfides.

\section{ACKNOWLEDGEMENTS}

This work was funded by the Norwegian Geological Survey (VM) and the Natural Sciences and Engineering Research Council of Canada and FCAR (SJB). This paper is a contribution to IGCP 427. Professor E.W. Sawyer is thanked for reading the early drafts of the manuscript and sketching the model figures. Both Drs. P.C. Lightfoot and J.P. Golightly are thanked for their efforts to make the manuscript intelligible. 


\section{REFERENCES}

Abzalov, M.Z. \& Both, R.A. (1997): The Pechenga Ni-Cu deposits, Russia: data on PGE and Au distribution and sulfur isotope compositions. Mineral. Petrol. 61, 119-143.

Amelin, Yu.V., Heaman, L.M. \& Semenov, V.S. (1995): U$\mathrm{Pb}$ geochronology of layered mafic intrusions in the eastern Baltic Shield: implications for the timing and duration of Paleoproterozoic continental rifting. Precamb. Res. 75, 31-46.

Barnes, S.-J., Couture, J.-F., Sawyer, E.W. \& Bouchaib, C. (1993): Nickel-copper sulfide occurrences in BelleterreAngliers belt of the Pontiac sub-province and the use of $\mathrm{Cu} / \mathrm{Pd}$ ratios in interpreting platinum-group element distributions. Econ. Geol. 88, 1402-1418.

\& OFTEN, M. (1990): Ti-rich komatiites from northern Norway. Contrib. Mineral. Petrol. 105, 42-54.

Picard, C.P., Giovenazzo, D. \& Tremblay, C. (1992): The composition of nickel-copper sulfide deposits and their host rocks from the Cape Smith Fold Belt, northern Quebec. Aust. J. Earth Sci. 39, 335-347.

\& THÉRIAULT, R.D. (1998): The influence of assimilation and cooling rate on the composition of magmatic sulfides: examples from Muskox and Duluth. In Eighth Int. Platinum Conf. (Rustenburg). S. Afr. Inst. Mining, Symp. Ser. S18, 29 (abstr.).

ZienteK, M. \& SEverson, M.J. (1997): Ni, Cu, Au and platinum-group element contents of sulfides associated with intraplate magmatism: a synthesis. Can. J. Earth Sci. 34, 337-351.

BÉDARD, P. \& BARNES, S.-J. (1990): Instrumental neutron activation analysis by collecting only one spectrum: results for international geochemical reference samples. Geostandards Newsletter 14, 479-484.

BERESFORD, S.W. \& CAS, R.A.F. (2001): Komatiitic invasive lava flows, Kambalda, Western Australia. Can. Mineral. 39, 525-535.

Brugmann, G.E., Hanski, E.J., NaldRett, A.J. \& SMOL'KIN, V.F. (2000): Sulphide segregation in ferropicrites from the Pechenga Complex, Kola Peninsula, Russia. J. Petrol. 41, $1721-1742$

CAlvert, S.E. (1976): The mineralogy and geochemistry of near shore sediments. In Chemical Oceanography 6 (J.R. Riley \& R.Chester, eds.). Academic Press, New York, N.Y.

CAmpbell, I.H. \& NALdRETT, A.J. (1979): The influence of silicate:sulfide ratios on the geochemistry of magmatic sulfides. Econ. Geol. 74, 1503-1506.

CAS, R.A.F. \& BERESFORD, S.W. (2001): Field characteristics and erosional processes associated with komatiitic lavas: implications for flow behavior. Can. Mineral. 39, 505-524.
Chadwick, J. (1992): Russia's Pechenganikel. Mining Mag 166(5), 270-274.

CRocket, J.H. (2000): PGE in fresh basalt, hydrothermal alteration products, and volcanic incrustations of Kilauea volcano, Hawaii. Geochim. Cosmochim. Acta 64, 17911807.

Distler, V.V., Filimonova, A.A., Grokhovskaya, T.L. \& LAPUTINA, I.P. (1990): Platinum-group elements in the copper-nickel ores of the Pechenga ore field. Int. Geol. Rev. 32, 70-83.

Francis, D., Ludden, J., Johnstone, R. \& Davis, W. (1999): Picrite evidence for more Fe in Archean mantle reservoirs. Earth Planet. Sci. Lett. 167, 197-213.

Gorbunov, G.I., Yakovlev, Yu.N., Goncharov, Yu.V., Gorelov, V.A. \& Tel'NOV, V.A. (1985): The nickel areas of the Kola Peninsula. Geol. Surv. Finland, Bull. 333, 41-66

Green, A.H. \& MelezhiK, V.A. (1999): Geology of the Pechenga ore deposits - a review with comments on ore forming processes. In Dynamic Processes in Magmatic Ore Deposits and their Application in Mineral Exploration (R.R. Keays, C.M. Lesher, P.C. Lightfoot \& C.E.G. Farrow, eds.). Geol. Assoc. Can., Short-Course Vol. 13, 287-328.

Greenough, J.D. \& Fryer, B.J. (1991): Distribution of Au, $\mathrm{Pd}, \mathrm{Pt}, \mathrm{Rh}, \mathrm{Ru}$ and Ir in ODP Leg 115, (Indian Ocean) hot spot basalts: implications for magmatic processes. In Proc. Ocean Drilling Program, Scientific Results (R.A. Duncan, J. Blackman, L.C. Peterson et al., eds.). 115, 71-84.

Grinenko, L.N., GrinenKo, V.A. \& LyakhnitzKaya, I.V. (1967): Isotopic composition of sulfides of the Kola Peninsula Ni-Cu deposits. Geology of the Ore Deposits 4, 3-17 (in Russ.).

\& SMOL'KIN, V.F. (1991): Isotopic composition and content of sulfur in the ferropicrites and gabbro-wehrlites of the Pechenga zone. Geochemistry 9, 1250-1261.

HANSKI, E.J. (1992): Petrology of the Pechenga ferropicrites and cogenetic, Ni-bearing gabbro-wehrlite intrusions, Kola Peninsula, Russia. Geol. Surv. Finland, Bull. 367.

\& SMOL'KIN, V.F. (1989): Pechenga ferropicrites and other Early Proterzoic picrites in the eastern part of the Baltic Shield. Precamb. Res. 45, 63-82.

Lagueux, J.-F. (1999). Pétrographie des gisements de $\mathrm{Ni}-\mathrm{Cu}$ de Pechenga, Russie. Projet de fin d'études, Université du Québec, Chicoutimi, Québec.

Lesher, C.M. \& CAmpbell, I.H. (1993): Geochemical and fluid dynamic modelling of compositional variations in Archean komatiite-hosted nickel sulfide ores in Western Australia. Econ. Geol. 88, 804-816.

McDonough, W.W. \& Sun, S.-S. (1995): The composition of the Earth. Chem. Geol. 120, 223-253. 
McKelvey, V.E., Everhart, D.L. \& Garrels, R.M. (1955): Origin of uranium deposits. Econ. Geol., 50th Anniv. Vol., 464-533.

MelezhiK, V.A., Grinenko, L.N. \& Fallick, A.E. (1998): 2000-Ma sulfide concretions from the "Productive" Formation of the Pechenga Greenstone Belt, NW Russia: genetic history based on morphological and isotopic evidence. Chem. Geol. 148, 61-94.

Hudson-Edwards, K.A., Green, A.H. \& GRINENKo, L.N. (1994): The Pechenga area, Russia. 2. Nickel-copper deposits and related rocks. Trans. Inst. Mining Metall., Sect. B 103, 146-161.

\& STURT, B.A. (1994): General geology and evolutionary history of the Early Proterozoic Polmak - Pasvik Pechenga - Imandra/Varzuga - Ust'Ponoy Greenstone Belt in the northeastern Baltic shield. Earth Sci. Rev. 36, 205241

, Mokrousov, V.A., Ramsay, D.M. \& Nilsson, L.P. (1995): The early Proterozoic PasvikPechenga Greenstone Belt: 1:200 000 geological map, stratigraphic correlation and revision of stratigraphic nomenclature. Norges Geol. Unders., Spec. Publ. 7, 81-91.

Peltonen, P. (1995): Magma - country rock interaction and the genesis of Ni-Cu deposits in the Vammala Nickel Belt, SW Finland. Mineral. Petrol. 52, 1-24.

Puchtel, I.S., Brügmann, G.E. \& Hofmann, A.E. (1999): Precise $\mathrm{Re}-\mathrm{Os}$ mineral isochron and $\mathrm{Pb}-\mathrm{Nd}-\mathrm{Os}$ isotope systematics of a mafic-ultramafic sill in the $2.0 \mathrm{Ga}$ Onega plateau (Baltic Shield). Earth Planet. Sci. Lett. 170, 447461.

RehKamper, M., Halliday, A.N., Fitton, J.G., Lee, D.-C., WiENEKe, M. \& ARNDT, N.T. (1999): Ir, Ru, Pt and Pd in basalts and komatiites: new constraints for the geochemical behavior of the platinum-group elements in the mantle. Geochim. Cosmochim. Acta 63, 3915-3934.
RIPLEY, E.M. (1981): Sulfur isotopic studies of the Dunka Road $\mathrm{Cu}-\mathrm{Ni}$ deposit, Duluth Complex, Minnesota. Econ. Geol. 76, 610-620.

SkuF'In, P.K. \& Fedotov, Z.A. (1989): Picritic pillow lavas in early Precambrian volcanic section of the Pechenga Zone. Dokl. Acad. Sci. USSR 306, 956-962.

SMOLKIN, V.F. (1977): Petrology of the Pilgujärvi ore-bearing intrusion (Pechenga). VINITI 2114-2177, 1-216.

(1992): Early Precambrian Picritic and Komatiitic Magmatism of the Baltic Shield. Nauka, St. Petersburg, Russia.

ThÉRIAUlt, R. \& BARNES, S.-J. (1998): Compositional variations in $\mathrm{Cu}-\mathrm{Ni}-\mathrm{PGE}$ sulfides of the Dunka Road deposit, Duluth Complex, Minnesota: the importance of combined assimilation and magmatic processes. Can. Mineral. 36, 869-886.

\& SEverson, M.J. (2000): Origin of $\mathrm{Cu}-$ $\mathrm{Ni}-\mathrm{PGE}$ sulfide mineralization in the Partridge River intrusion, Duluth Complex, Minnesota. Econ. Geol. 95, 929-943.

Walker, R.J., Morgan, J.W., Hanski, E.J. \& SMOl'Kin, V.F. (1997): Re-Os systematics of Early Proterozoic ferropicrites, Pechenga Complex, northwestern Russia: evidence for ancient ${ }^{187}$ Os-enriched plumes. Geochim. Cosmochim. Acta 61, 3145-3160.

Zak, S.I., Makarov, V.N., Kochnev-Pervukhov, V.I., Proskuryokov, V.V., Zaskingd, E.S., Batashev, E.V. \& Kolesnikov, G.P. (1982): Geology, Magmatism and Ore Formation in the Pechenga Ore Field. Nedra, Leningrad, Russia.

Received November 3, 1999, revised manuscript accepted December 15, 2000.0 